\title{
External Shocks, Financial Volatility and Reserve Requirements in an Open Economy
}

DOI:

10.1016/j.jimonfin.2018.01.003

\section{Document Version}

Accepted author manuscript

Link to publication record in Manchester Research Explorer

\section{Citation for published version (APA):}

Agenor, P-R., Alper, K., \& Pereira da Silva, L. A. (2018). External Shocks, Financial Volatility and Reserve Requirements in an Open Economy. Journal of International Money and Finance, 83, 23-43.

https://doi.org/10.1016/j.jimonfin.2018.01.003

\section{Published in:}

Journal of International Money and Finance

\section{Citing this paper}

Please note that where the full-text provided on Manchester Research Explorer is the Author Accepted Manuscript or Proof version this may differ from the final Published version. If citing, it is advised that you check and use the publisher's definitive version.

\section{General rights}

Copyright and moral rights for the publications made accessible in the Research Explorer are retained by the authors and/or other copyright owners and it is a condition of accessing publications that users recognise and abide by the legal requirements associated with these rights.

\section{Takedown policy}

If you believe that this document breaches copyright please refer to the University of Manchester's Takedown Procedures [http://man.ac.uk/04Y6Bo] or contact uml.scholarlycommunications@manchester.ac.uk providing relevant details, so we can investigate your claim.

\section{OPEN ACCESS}




\title{
External Shocks, Financial Volatility and Reserve Requirements in an Open Economy
}

\author{
Pierre-Richard Agénor* \\ School of Social Sciences, University of Manchester \\ Koray Alper \\ European Investment Bank, Luxembourg \\ Luiz Pereira da Silva \\ Bank for International Settlements, Basel \\ Final version: January 21, 2018 \\ Forthcoming, Journal of International Money and Finance
}

\begin{abstract}
The performance of a simple, countercyclical reserve requirement rule is studied in a dynamic stochastic model of a small open economy with financial frictions, imperfect capital mobility, a managed float regime, and sterilized foreign exchange market intervention. Bank funding sources, domestic and foreign, are imperfect substitutes. The model is calibrated and used to study the effects of a temporary drop in the world risk-free interest rate. Consistent with stylized facts, the shock triggers an expansion in domestic credit and activity, asset price pressures, and a real appreciation. An optimal, credit-based reserve requirement rule, based on minimizing a composite loss function, helps to mitigate both macroeconomic and financial volatility - with the latter defined both in terms of a narrow measure based on the credit-to-output ratio, the ratio of capital flows to output, and interest rate spreads, and a broader measure that includes real asset prices as well. Greater reliance on sterilization implies a less aggressive optimal reserve requirements rule, implying that the two instruments are partial substitutes.
\end{abstract}

JEL Classification Numbers: E32, E58, F41.

\footnotetext{
*Corresponding author, email address: pierre-richard.agenor@manchester.ac.uk, phone: +44 161 306 6563. We are grateful to Alessandro Flamini, André Minella, Peter Montiel, Fabia de Carvalho, participants at various seminars and an anonymous referee for helpful discussions and comments, although the views expressed in this paper are our own. A longer version of this article, containing some sensitivity analysis and Appendices A to C, is available upon request.
} 


\section{Introduction}

A key lesson of the global financial crisis is the importance of going beyond a microprudential approach, focused solely on the regulation of individual institutions, and adopt instead a macroprudential perspective for containing systemic risks and preserve financial and economic stability. At the same time, the greater focus on systemic risk has fostered a broad debate in academic and policy circles on how macroprudential regulation can prevent asset price pressures and unsustainable credit booms. Even though no consensus has yet emerged on what instruments are most appropriate and under which circumstances, some of them have already been made part of the Basel III regime for banking regulation (see Basel Committee on Banking Supervision $(2011,2013)$ ).

Among these instruments figures reserve requirements, which are often thought of as a liquidity management tool. However, in recent years they have been used extensively in middle-income countries (MICs) for a broader set of purposes. Both Brazil and Turkey, for instance, lowered required reserve ratios in response to the collapse of Lehman Brothers in 2008 and increased them again in the period of large capital inflows that occurred between 2010 to mid-2011. ${ }^{1}$ Other Latin American countries, such as Colombia and Peru, have also used this instrument aggressively (Vargas et al. (2010) and Tovar et al. (2012)). More generally, there is evidence showing that central banks in a broad group of MICs have often raised reserve requirements in response to capital inflows (Hoffmann and Löffler (2014)) and rapid credit growth (Federico et al. (2014), Cerutti et al. (2017), and Fendoglu (2017)).

This paper contributes to the debate on the role of reserve requirements on domesticcurrency deposits in several ways. It extends the model in Agénor et al. (2014) to account for several important financial and policy features of MICs: a managed float; sterilized foreign exchange market intervention; and imperfect substitutability between deposits and central bank borrowing as sources of funding for commercial banks. The first two extensions are consistent with the evidence suggesting that many MICs operate a managed float regime, and the fact that sterilized intervention - rather than the policy interest rate - is the main instrument used by many emerging market and developing country central banks to affect the exchange rate. Indeed, as discussed by Chang (2008), Aizenman and Glick (2009), and Devereux and Yetman (2014), sterilization activity has

\footnotetext{
${ }^{1}$ See Robitaille (2011), Glocker and Towbin (2015), and Barroso et al. (2017) for Brazil, and Mimir et al. (2013) for Turkey.
} 
played an important role in central bank policy responses to surges in capital inflows; its use has actually intensified in several countries since the global financial crisis. Even though the feasibility and effectiveness of sterilization remain a matter of debate (see Daude et al. (2016)), this may well have been the consequence of a greater weight on mitigating exchange rate volatility. We also account for the possibility that changes in official reserves may be driven by other considerations, namely, self-insurance motives.

The model accounts as well for imperfect substitutability between deposits and central bank liquidity as sources of commercial bank funding. This is captured by assuming that the rate at which banks can borrow from the central bank incorporates a premium (above and beyond a base policy rate), which depends on the ratio of existing borrowing to deposits. Thus, because higher reserve requirements hamper the ability to attract deposits, they also lead (all else equal) to an increase in the cost of central bank liquidity, which in turn affects the cost at which private agents can borrow. As it turns out, this is the key channel through which changes in reserve requirements may operate in countercyclical fashion.

Our key findings (based on a parameterization that replicates the main stylized facts associated with episodes of large capital inflows driven by external shocks) are twofold. First, in response to a drop in the world risk-free rate an optimal, creditbased reserve requirement rule may help to mitigate both macroeconomic and financial volatility, with the latter defined either in terms of a narrow measure based on the credit-to-output ratio, the ratio of capital flows to output, and interest rate spreads, or in terms of a broader measure that includes also real asset prices. Second, if the quasifiscal costs of sterilization - which may be substantial in practice - are not accounted for in the central bank's loss function, it is optimal to fully sterilize, even when an optimal countercyclical reserve requirements rule is in place. In that sense, the two instruments are complements. Moreover, greater reliance on sterilization implies a less aggressive optimal reserve requirements rule, which implies that the two instruments are partial substitutes at the margin.

The remainder of the paper is organized as follows. ${ }^{2}$ Section 2 gives a formal description of the model. As in Agénor et al. (2014), the model features imperfect capital mobility and a two-level financial intermediation system, which accounts for bank bor-

\footnotetext{
${ }^{2}$ The working paper version of this article provides a review of the litterature on the use of reserve requirements and an intuitive discussion of their countercyclical role.
} 
rowing abroad - an important feature of cross-border capital flows in recent years. ${ }^{3}$ In addition, as noted earlier, several novel elements are introduced: exchange rate smoothing, self insurance, sterilized foreign exchange market intervention, and imperfect substitutability between bank borrowing from the central bank and deposits. The equilibrium and some key features of the steady state are discussed in Section 3, and an illustrative parameterization is presented in Section 4. The results of our main experiment, a temporary drop in the world safe interest rate, are described in Section 5. The performance of the model with an arbitrary countercyclical reserve requirement rule is discussed in Section 6, whereas the optimal rule is discussed in Section 7. The concluding section discusses the policy implications of the analysis for middle-income countries.

\section{The Model}

Consider a small open economy populated by seven categories of agents: a continuum of households with unit mass, a continuum of intermediate goods-producing (IG) firms, indexed by $j \in(0,1)$, a representative final good (FG) producer, a continuum of capital good (CG) producers with unit mass, a continuum of commercial banks, indexed by $i \in(0,1)$, the government, and the central bank. For simplicity, each household is matched to an IG producer, a CG producer, and a bank, and receives profits from all of them. The country produces a continuum of intermediate goods, which are imperfect substitutes to a continuum of imported intermediate goods. Both categories of goods are aggregated to produce a homogeneous final good. In turn, the final good is consumed by households and the government, used for investment by CG producers, or exported. Monopolistic competition prevails in the market for domestic intermediate goods and each intermediate good is produced or imported by a single firm. Banks are also monopolistically competitive.

\footnotetext{
${ }^{3}$ See Hoggarth et al. (2010), Committee on International Economic Policy and Reform (2012), Herrmann and Mihaljek (2013), and Reinhardt and Riddiough (2014) for a discussion of the importance of cross-border bank flows - especially changes in the external liabilities of resident banks - in international capital movements during the run up to, and the immediate aftermath of, the global financial crisis.
} 


\subsection{Households}

The representative household consumes the final good, demands housing services, supplies labor, and holds imperfectly substitutable domestic assets (cash, deposits, and government bonds) and foreign bonds. It owns all domestic firms. The household's objective is to maximize

$$
U_{t}=\mathbb{E}_{t} \sum_{s=0}^{\infty} \Lambda^{s}\left\{\frac{C_{t+s}^{1-\varsigma^{-1}}}{1-\varsigma^{-1}}+\eta_{N} \ln \left(1-N_{t+s}\right)+\eta_{x} \ln x_{t+s}+\eta_{H} \ln H_{t+s}\right\}
$$

where $C_{t}$ is consumption, $N_{t}=\int_{0}^{1} N_{t}^{j} d j$, the share of total time endowment (normalized to unity) spent working, with $N_{t}^{j}$ denoting the number of hours of labor provided to IG producer $j, x_{t}$ a composite index of real monetary assets, $H_{t}$ the stock of housing, $\Lambda \in$ $(0,1)$ the subjective discount factor, $\varsigma>0$ the intertemporal elasticity of substitution in consumption, $\mathbb{E}_{t}$ the expectation operator conditional on the information available at the beginning of period $t$, and $\eta_{N}, \eta_{x}, \eta_{H}>0$. Housing services are proportional to their stock.

The composite monetary asset is a geometric average of real cash balances, $m_{t}^{P}$, and real bank deposits, $d_{t}$, both of which provide liquidity services:

$$
x_{t}=\left(m_{t}^{P}\right)^{\nu} d_{t}^{1-\nu}
$$

where $\nu \in(0,1)$. Both $m_{t}^{P}$ and $d_{t}$ are measured in terms of the price of goods sold on the domestic market, $P_{t}^{S}$.

The household's flow budget constraint is

$$
\begin{gathered}
m_{t}^{P}+d_{t}+b_{t}^{P}+z_{t} B_{t}^{F, P}+p_{t}^{H} \Delta H_{t} \\
=w_{t} N_{t}-T_{t}-C_{t}+\frac{m_{t-1}^{P}}{1+\pi_{t}^{S}}+\left(\frac{1+i_{t-1}^{D}}{1+\pi_{t}^{S}}\right) d_{t-1}+\left(\frac{1+i_{t-1}^{B}}{1+\pi_{t}^{S}}\right) b_{t-1}^{P} \\
+\left(1+i_{t-1}^{F, P}\right) z_{t} B_{t-1}^{F, P}+J_{t}^{D}+J_{t}^{K}+J_{t}^{B}
\end{gathered}
$$

where $z_{t}=E_{t} / P_{t}^{S}$ is the real exchange rate (with $E_{t}$ the nominal exchange rate), $p_{t}^{H}=$ $P_{t}^{H} / P_{t}^{S}$ the real price of housing (with $P_{t}^{H}$ the nominal price), $1+\pi_{t}^{S}=P_{t}^{S} / P_{t-1}^{S}, H_{t}$ the stock of housing, $b_{t}^{P}\left(B_{t}^{F, P}\right)$ real (foreign-currency) holdings of one-period, noncontingent domestic (foreign) government bonds, $i_{t}^{D}$ the interest rate on bank deposits, $i_{t}^{B}$ and $i_{t}^{F, P}$ interest rates on domestic and foreign government bonds, respectively, $w_{t}$ the economywide real wage (measured in terms of the price of final goods sold domestically), $T_{t}$ real 
lump-sum taxes, and $J_{t}^{D}, J_{t}^{K}$, and $J_{t}^{B}$ end-of-period profits of the matched IG producer, CG producer, and commercial bank, respectively. ${ }^{4}$ For simplicity, housing does not depreciate and domestic government bonds are held only at home.

The rate of return on foreign bonds is defined as

$$
1+i_{t}^{F, P}=\left(1+i_{t}^{W}\right)\left(1-\theta_{t}^{F, P}\right)
$$

where $i_{t}^{W}$ is the risk-free world interest rate and $\theta_{t}^{F, P}$ an endogenous spread, defined as

$$
\theta_{t}^{F, P}=\frac{\theta_{0}^{F, P}}{2} B_{t}^{F, P}
$$

with $\theta_{0}^{F, P}>0$. Thus, in contrast to models where the country's borrowing premium depends on total net foreign indebtedness (as for instance in Gertler et al. (2007)), the household internalizes the fact that its holdings of foreign bonds affect the premium that it faces on world capital markets.

The household maximizes (1) with respect to $C_{t}, N_{t}, m_{t+1}^{P}, d_{t+1}, b_{t+1}^{P}, B_{t+1}^{F, P}$, and $H_{t+1}$, subject to (2) to (5), taking as given period- $t-1$ variables as well as $w_{t}, T_{t}$, and real profits. The first-order conditions are

$$
\begin{gathered}
\mathbb{E}_{t}\left(\frac{C_{t+1}}{C_{t}}\right)=\Lambda \mathbb{E}_{t}\left(\frac{1+i_{t}^{B}}{1+\pi_{t+1}^{S}}\right)^{\varsigma}, \\
N_{t}=1-\frac{\eta_{N} C_{t}^{1 / \varsigma}}{w_{t}}, \\
m_{t}^{P}=\frac{\eta_{x} \nu C_{t}^{1 / \varsigma}\left(1+i_{t}^{B}\right)}{i_{t}^{B}}, \\
d_{t}=\frac{\eta_{x}(1-\nu) C_{t}^{1 / \varsigma}\left(1+i_{t}^{B}\right)}{i_{t}^{B}-i_{t}^{D}}, \\
p_{t}^{H} H_{t}=\left\{1-\mathbb{E}_{t}\left(\frac{1+\pi_{t+1}^{H}}{1+i_{t}^{B}}\right)\right\}^{-1} \eta_{H} C_{t}^{1 / \varsigma}, \\
1+i_{t}^{B}=\left(1-\theta_{0}^{F, P} B_{t}^{F, P}\right)\left(1+i_{t}^{W}\right) \mathbb{E}_{t}\left(\frac{E_{t+1}}{E_{t}}\right),
\end{gathered}
$$

where $1+\pi_{t+1}^{H}=P_{t+1}^{H} / P_{t}^{H}$ is the gross inflation rate in terms of nominal house prices.

Equation (6) is the Euler equation, whereas equations (7) to (9) define labor supply, the demand for cash, and the demand for deposits, respectively. Equation (10) defines

\footnotetext{
${ }^{4}$ The definition of the real exchange rate assumes that the foreign-currency price of final goods sold on markets abroad is normalized to unity.
} 
the demand for housing services, whereas equation (11) equates the expected marginal rates of return on domestic and foreign assets under the assumption of imperfect world capital markets; it can be rearranged to give

$$
B_{t}^{F, P}=\frac{\left(1+i_{t}^{W}\right) \mathbb{E}_{t}\left(E_{t+1} / E_{t}\right)-\left(1+i_{t}^{B}\right)}{\theta_{0}^{F, P}\left(1+i_{t}^{W}\right) \mathbb{E}_{t}\left(E_{t+1} / E_{t}\right)} .
$$

which shows that the optimal level of household holdings of foreign bonds is a function of the difference between the expected, depreciation-adjusted world safe interest rate and the domestic bond rate. Perfect capital mobility prevails when $\theta_{0}^{F, P} \rightarrow 0$, in which case $1+i_{t}^{B}=\left(1+i_{t}^{W}\right) \mathbb{E}_{t}\left(E_{t+1} / E_{t}\right)$, corresponding to the standard uncovered interest parity condition under risk neutrality. ${ }^{5}$

The risk-free world interest rate follows a first-order autoregressive process:

$$
\frac{1+i_{t}^{W}}{1+\tilde{\imath}^{W}}=\left(\frac{1+i_{t-1}^{W}}{1+\tilde{\imath}^{W}}\right)^{\rho_{W}} \exp \left(\xi_{t}^{W}\right)
$$

where $\rho_{W} \in(0,1), \xi_{t}^{W} \sim N\left(0, \sigma_{\xi^{W}}\right)$, and a tilde is used to denote a steady-state value.

\subsection{Domestic Final Good}

The FG producer imports a continuum of differentiated intermediate goods from the rest of the world and combines them with a similar continuum of domestically-produced intermediate goods to generate a domestic final good, in quantity $Y_{t}$, which is sold both domestically (for consumption and investment) and abroad:

$$
Y_{t}=\left[\Lambda_{D}\left(Y_{t}^{D}\right)^{(\eta-1) / \eta}+\left(1-\Lambda_{D}\right)\left(Y_{t}^{F}\right)^{(\eta-1) / \eta}\right]^{\eta /(\eta-1)}
$$

where $\Lambda_{D} \in(0,1), Y_{t}^{D}\left(Y_{t}^{F}\right)$ is a quantity index of domestic (imported) intermediate goods, and $\eta>0$ is the elasticity of substitution between baskets of domestic and imported composite intermediate goods. These baskets are defined as

$$
Y_{t}^{k}=\left\{\int_{0}^{1}\left[Y_{j t}^{k}\right]^{\left(\theta_{k}-1\right) / \theta_{k}} d j\right\}^{\theta_{k} /\left(\theta_{k}-1\right)}, \quad k=D, F
$$

where $\theta_{k}>1$ is the elasticity of substitution between intermediate domestic goods among themselves $(k=D)$, and imported goods among themselves $(k=F)$, and $Y_{j t}^{k}$ is the quantity of intermediate good $j$ of type $k$ (domestic or imported), with $j \in(0,1)$.

\footnotetext{
${ }^{5}$ The specification used here follows Agénor (1997); see for instance Lartey (2012), Gabaix and Maggiori (2014), and Liu and Spiegel (2014) for alternative ways of modeling imperfect asset substitutability in an open economy.
} 
The FG producer sells its output at a perfectly competitive price. Let $P_{j t}^{D}$ denote the price of domestic intermediate good $j$ set by firm $j$, and $P_{j t}^{F}$ the price of imported intermediate good $j$, in domestic currency. Cost minimization yields the demand functions for each variety of intermediate goods:

$$
Y_{j t}^{k}=\left(\frac{P_{j t}^{k}}{P_{t}^{k}}\right)^{-\theta_{i}} Y_{t}^{i}, \quad k=D, F
$$

where $P_{t}^{D}$ and $P_{t}^{F}$ are price indices for domestic and imported intermediate goods, respectively, which are given from the zero-profit condition as

$$
P_{t}^{k}=\left\{\int_{0}^{1}\left(P_{j t}^{k}\right)^{1-\theta_{k}} d j\right\}^{1 /\left(1-\theta_{k}\right)} \cdot k=D, F
$$

Aggregating across firms yields the allocation of total demand between domestic and foreign goods:

$$
Y_{t}^{D}=\Lambda_{D}^{\eta}\left(\frac{P_{t}^{D}}{P_{t}}\right)^{-\eta} Y_{t}, \quad Y_{t}^{F}=\left(1-\Lambda_{D}\right)^{\eta}\left(\frac{P_{t}^{F}}{P_{t}}\right)^{-\eta} Y_{t}
$$

where $P_{t}$ is the price of final output, given by

$$
P_{t}=\left[\Lambda_{D}^{\eta}\left(P_{t}^{D}\right)^{1-\eta}+\left(1-\Lambda_{D}\right)^{\eta}\left(P_{t}^{F}\right)^{1-\eta}\right]^{1 /(1-\eta)} .
$$

Given our focus, imperfect exchange rate pass-through is accounted for in a simple manner. In the absence of transportation costs, the domestic-currency price of imports of intermediate good $j$ is given by

$$
P_{j t}^{F}=E_{t}^{\mu^{F}} E_{t-1}^{1-\mu^{F}} W P_{j t}^{F},
$$

where $W P_{j t}^{F}$ is the foreign-currency price of imported good $j$ and $\mu^{F} \in(0,1)$ measures the degree of exchange rate pass-through. Thus, $\mu^{F}=1$ corresponds to instantaneous, complete pass-through (that is, local currency pricing). ${ }^{6}$ Regardless of the value of $\mu^{F}$, complete pass-through occurs in the long run.

The volume of goods sold abroad, $Y_{t}^{X}$, depends on the domestic-currency price of exports of the final good, $P_{t}^{X}$, relative to the price of goods sold on the domestic market:

$$
Y_{t}^{X}=\left(\frac{P_{t}^{X}}{P_{t}^{S}}\right)^{\varkappa}
$$

where $\varkappa>0$ and $P_{t}^{X}$ is defined as

$$
P_{t}^{X}=E_{t} W P_{t}^{X}
$$

\footnotetext{
${ }^{6}$ See for instance Shi and Xu (2010) and Adolfson et al. (2014) for a full treatment with a monopolistically competitive import goods sector.
} 
with $W P_{t}^{X}$ denoting the foreign-currency price of exports.

Total output in volume terms is also given by

$$
Y_{t}=Y_{t}^{S}+Y_{t}^{X}
$$

where $Y_{t}^{S}$ denotes the volume of goods sold on the domestic market.

\subsection{Domestic Intermediate Goods}

Domestic IG firms, indexed by $j \in(0,1)$, produce intermediate goods by combining labor, $N_{j t}$, and capital, $K_{j t}$ :

$$
Y_{j t}^{D}=N_{j t}^{1-\alpha} K_{j t}^{\alpha}, \quad \alpha \in(0,1)
$$

Each IG producer rents capital from a randomly matched CG producer, at the rate $r_{t}^{K}$, and pays for it after the sale of output. However, a fraction $\kappa^{W} \in(0,1)$ of wages must be paid in advance. To do so firm $j$ borrows from banks the amount $l_{t}^{W, j}$, given by

$$
l_{t}^{W, j}=\kappa^{W} w_{t} N_{j t}
$$

Loans contracted for the purpose of financing working capital do not carry any risk, and are made at a rate that reflects only the marginal cost of borrowing from the central bank, $i_{t}^{C}$. Total costs of firm $j$ in period $t, T C_{j t}$, are thus given by

$$
T C_{j t}=\left(1+i_{t}^{C}\right) \kappa^{W} w_{t} N_{j t}+r_{t}^{K} K_{j t}
$$

In standard fashion, cost minimization yields the capital-labor ratio and the unit real marginal cost, $m c_{t}$, as

$$
\begin{aligned}
\frac{K_{j t}}{N_{j t}} & =\left(\frac{\alpha}{1-\alpha}\right)\left[\frac{\left(1+\kappa^{W} i_{t}^{C}\right) w_{t}}{r_{t}^{K}}\right], \\
m c_{t} & =\left(\frac{r_{t}^{K}}{\alpha}\right)^{\alpha}\left[\frac{\left(1+\kappa^{W} i_{t}^{C}\right) w_{t}}{1-\alpha}\right]^{1-\alpha} .
\end{aligned}
$$

Domestic IG producers incur a Rotemberg-type cost in adjusting prices, of the form $\left(\phi_{D} / 2\right)\left[\left(P_{j t}^{D} / P_{j t-1}^{D}\right)-1\right]^{2} Y_{t}^{D}$, where $\phi_{D} \geq 0 .{ }^{7}$ Under monopolistically competitive markets, each firm $j$ chooses a sequence of prices so as to maximize the discounted value of its current and future profits:

$$
\left\{P_{j t+s}^{D}\right\}_{s=0}^{\infty}=\arg \max \mathbb{E}_{t} \sum_{s=0}^{\infty} \Lambda^{s} \lambda_{t+s} J_{j t+s}^{D},
$$

\footnotetext{
${ }^{7}$ In this expression, the steady-state inflation rate in the price of goods sold domestically is zero.
} 
where $J_{j t+s}^{D}$ denotes real profits at $t$, defined as

$$
J_{j t}^{D}=\left(\frac{P_{j t}^{D}}{P_{t}^{D}}\right) Y_{j t}^{D}-m c_{t} Y_{j t}^{D}-\frac{\phi_{D}}{2}\left(\frac{P_{j t}^{D}}{P_{j t-1}^{D}}-1\right)^{2} Y_{t}^{D} .
$$

Taking $\left\{m c_{t+s}, P_{t+s}^{D}, Y_{t+s}^{D}\right\}_{s=0}^{\infty}$ as given, and using (15) with $k=D$, the first-order condition for this maximization problem is:

$$
\begin{gathered}
\left(1-\theta_{D}\right)\left(\frac{P_{j t}^{D}}{P_{t}^{D}}\right)^{-\theta_{D}} \frac{1}{P_{t}^{D}}+\theta_{D}\left(\frac{P_{j t}^{D}}{P_{t}^{D}}\right)^{-\theta_{D}-1} \frac{m c_{t}}{P_{t}^{D}} \\
-\phi_{D}\left\{\left(\frac{P_{j t}^{D}}{P_{j t-1}^{D}}-1\right) \frac{1}{P_{j t-1}^{D}}\right\}+\Lambda \phi_{D} \mathbb{E}_{t}\left\{\frac{\lambda_{t+1}}{\lambda_{t}}\left(\frac{P_{j t+1}^{D}}{P_{j t}^{D}}-1\right) \frac{P_{j t+1}^{D}}{\left(P_{j t}^{D}\right)^{2}} \frac{Y_{t+1}^{D}}{Y_{t}^{D}}\right\}=0,
\end{gathered}
$$

which determines the adjustment process of the nominal price $P_{j t}^{D}$.

\subsection{Capital Good}

At the beginning of the period, the representative CG producer buys an amount $I_{t}$ of the final good from the FG producer and combines it with the existing capital stock to produce new capital goods, $K_{t+1}$, which are rented in the next period to a randomly matched IG producer at the rate $r_{t+1}^{K}$. Capital accumulates as follows:

$$
K_{t+1}=\left\{\frac{I_{t}}{K_{t}}-\frac{\Theta_{K}}{2}\left(\frac{K_{t+1}-K_{t}}{K_{t}}\right)^{2}\right\} K_{t}+(1-\delta) K_{t},
$$

where $\delta \in(0,1)$ is a constant rate of depreciation, and $\Theta_{K}>0$ is a parameter that measures the magnitude of adjustment costs. Investment goods must be paid in advance; the representative $\mathrm{CG}$ producer must therefore borrow from banks, at the rate $i_{t}^{L}$, the amount

$$
l_{t}^{I}=I_{t}
$$

The matched household makes its housing stock, $\bar{H}$, available at no direct charge (for simplicity) to the CG producer, who uses it as collateral against which it borrows. Repayment is uncertain and occurs with probability $q_{t} \in(0,1)$. Expected repayment is thus $q_{t}\left(1+i_{t}^{L}\right) I_{t}+\left(1-q_{t}\right) \kappa p_{t}^{H} \bar{H}$, where $\kappa=\int_{0}^{1} \kappa^{i} d i \leq 1$ and $\kappa^{i} \in(0,1)$ is the fraction of the housing stock pledged as collateral to each bank $i$.

Subject to (30) and (31), the representative CG producer chooses the level of capital $K_{t+1}$ (taking the rental rate, the lending rate, and the existing capital stock as given) so 
as to maximize the value of the discounted stream of dividend payments to the matched household:

$$
\left\{K_{t+s+1}\right\}_{s=0}^{\infty}=\arg \max \sum_{s=0}^{\infty} \Lambda^{s} \mathbb{E}_{t}\left(\lambda_{t+s} J_{t+s+1}^{K}\right),
$$

where $\lambda_{t+s}=C_{t+s}^{-1 / \varsigma}$ is the marginal utility value (in terms of consumption) of an additional currency unit of real profits at $t+s$ and $J_{t+s+1}^{K}$ denotes profits at the end of period $t+s$, defined as

$$
J_{t+s+1}^{K}=r_{t+s}^{K} K_{t+s}-q_{t+s}\left(1+i_{t+s}^{L}\right) I_{t+s}-\left(1-q_{t+s}\right) \kappa p_{t+s}^{H} \bar{H}
$$

Using (6), the first-order condition for maximization can be written as

$$
\begin{gathered}
\mathbb{E}_{t} r_{t+1}^{K}=q_{t}\left(1+i_{t}^{L}\right) \mathbb{E}_{t}\left\{\left[1+\Theta_{K}\left(\frac{K_{t+1}}{K_{t}}-1\right)\right]\left(\frac{1+i_{t}^{B}}{1+\pi_{t+1}^{S}}\right)\right\} \\
-\mathbb{E}_{t}\left\{q_{t+1}\left(1+i_{t+1}^{L}\right)\left\{1-\delta+\frac{\Theta_{K}}{2}\left[\left(\frac{K_{t+2}}{K_{t+1}}\right)^{2}-1\right]\right\}\right\},
\end{gathered}
$$

which relates the expected rate of return on the capital stock to the expected marginal cost of investing.

The amount borrowed by the representative CG producer is a Dixit-Stiglitz basket of differentiated loans, each supplied by a bank $i$, with an elasticity of substitution $\zeta^{L}>1$ :

$$
l_{t}^{I}=\left[\int_{0}^{1}\left(l_{t}^{I, i}\right)^{\left(\zeta^{L}-1\right) / \zeta} d i\right]^{\zeta^{L} /\left(\zeta^{L}-1\right)} .
$$

The demand for type- $i$ loan, $l_{t}^{I, i}$, is thus given by the downward-sloping curve

$$
l_{t}^{I, i}=\left(\frac{1+i_{t}^{L, i}}{1+i_{t}^{L}}\right)^{-\zeta^{L}} l_{t}^{I},
$$

where $i_{t}^{L, i}$ is the interest rate on the loan extended by bank $i$ and $i_{t}^{L}=\left[\int_{0}^{1}(1+\right.$ $\left.\left.i_{t}^{L, i}\right)^{1-\zeta^{L}} d i\right]^{1 /\left(1-\zeta^{L}\right)}-1$ the aggregate loan rate.

\subsection{Commercial Banks}

Banks, indexed by $i \in(0,1)$, are monopolistically competitive. They collect differentiated deposits from households and extend differentiated loans to IG and CG producers. They also borrow on world capital markets and from the central bank. At the end of each period, each bank repays with interest household deposits and the liquidity borrowed from the central bank, and redeems in full its foreign debt. All profits are then distributed. 
Bank $i$ 's balance sheet is

$$
l_{t}^{i}+R R_{t}^{i}=d_{t}^{i}+z_{t} L_{t}^{F, B, i}+l_{t}^{C, B, i}
$$

where $l_{t}^{i}=l_{t}^{W, i}+l_{t}^{I, i}, L_{t}^{F, B, i}$ is foreign borrowing (in foreign-currency terms), $l_{t}^{C, B, i}$ borrowing from the central bank, and $R R_{t}^{i}$ required reserves, which must be held at all times at the central bank and do not pay interest; they are set as a fraction $\mu_{t}^{R} \in(0,1)$ of deposit liabilities:

$$
R R_{t}^{i}=\mu_{t}^{R} d_{t}^{i}
$$

The aggregate supply of deposits by households is a basket of differentiated deposits, each supplied to a bank $i$, with a constant elasticity of substitution $\zeta^{D}>1$ between different types of deposits:

$$
d_{t}=\left[\int_{0}^{1}\left(d_{t}^{i}\right)^{\left(1+\zeta^{D}\right) / \zeta^{D}} d i\right]^{\zeta^{D} /\left(1+\zeta^{D}\right)}
$$

The supply of type- $i$ deposit, $d_{t}^{i}$, is thus given by the upward-sloping curve

$$
d_{t}^{i}=\left(\frac{1+i_{t}^{D, i}}{1+i_{t}^{D}}\right)^{\zeta^{D}} d_{t}
$$

where $i_{t}^{D, i}$ is the deposit rate set by bank $i$ and $i_{t}^{D}=\left[\int_{0}^{1}\left(1+i_{t}^{D, i}\right)^{1+\zeta^{D}} d i\right]^{1 /\left(1+\zeta^{D}\right)}-1$ the aggregate deposit rate.

The bank's cost of borrowing on world capital markets, $i_{t}^{F, B, i}$, measured in foreigncurrency terms, is defined as

$$
1+i_{t}^{F, B, i}=\left(1+i_{t}^{W}\right)\left(1+\theta_{t}^{F, B, i}\right)
$$

where $\theta_{t}^{F, B, i}$ is a premium that increases with the amount borrowed:

$$
\theta_{t}^{F, B, i}=\frac{\theta_{0}^{F, B}}{2} L_{t}^{F, B, i}, \quad \theta_{0}^{F, B}>0
$$

Bank $i$ 's expected real profits at the end of period $t$ are defined as

$$
\begin{gathered}
\mathbb{E}_{t} J_{t+1}^{B, i}=\left(1+i_{t}^{C}\right) l_{t}^{W, i}+q_{t}^{i}\left(1+i_{t}^{L, i}\right) l_{t}^{I, i}+\left(1-q_{t}^{i}\right) \kappa^{i} p_{t}^{H} \bar{H} \\
-\left(1+i_{t}^{D, i}\right) d_{t}^{i}-\left(1+i_{t}^{C}\right) l_{t}^{C, B, i}-\left(1+i_{t}^{F, B, i}\right) \mathbb{E}_{t}\left(\frac{E_{t+1}}{E_{t}}\right) z_{t} L_{t}^{F, B, i},
\end{gathered}
$$

where $q_{t}^{i}\left(1+i_{t}^{L, i}\right) I_{t}+\left(1-q_{t}^{i}\right) \kappa^{i} p_{t}^{H} \bar{H}$ is expected repayment to bank $i$. 
Each bank sets the gross deposit and lending rates and determines foreign borrowing so as to maximize expected profits, as defined in (40), subject to (34) and (35)-(39). Solving this problem yields, in a symmetric equilibrium, ${ }^{8}$

$$
\begin{gathered}
i_{t}^{D}=\frac{\zeta^{D}}{1+\zeta^{D}}\left(1-\mu_{t}^{R}\right)\left(1+i_{t}^{C}\right)-1, \\
i_{t}^{L}=\frac{\zeta^{L}}{q_{t}\left(\zeta^{L}-1\right)}\left(1+i_{t}^{C}\right)-1, \\
L_{t}^{F, B}=\frac{1+i_{t}^{C}-\left(1+i_{t}^{W}\right) \mathbb{E}_{t}\left(E_{t+1} / E_{t}\right)}{\theta_{0}^{F, B}\left(1+i_{t}^{W}\right) \mathbb{E}_{t}\left(E_{t+1} / E_{t}\right)} .
\end{gathered}
$$

Equation (41) shows that the equilibrium deposit rate is a markup over the refinance rate, adjusted (downward) for the implicit cost of holding reserve requirements. Equation (42) indicates that the lending rate depends negatively on the repayment probability and positively on the marginal cost of borrowing from the central bank. Equation (43) states that foreign borrowing is decreasing (increasing) in the cost of borrowing abroad (domestically).

As in Agénor et al. (2013, 2014), the repayment probability depends positively on the effective collateral-CG loan ratio and the cyclical position of the economy:

$$
q_{t}=\left(\frac{\kappa p_{t}^{H} \bar{H}}{l_{t}^{I}}\right)^{\varphi_{1}}\left(\frac{Y_{t}^{S}}{\tilde{Y}^{S}}\right)^{\varphi_{2}},
$$

with $\varphi_{1}, \varphi_{2}>0$ and $\tilde{Y}^{S}$ is the steady-state level of output sold domestically. ${ }^{9}$

Borrowing from the central bank is determined residually from the balance sheet constraint (35).

\subsection{Central Bank}

The central bank supplies liquidity to commercial banks through a standing facility, but at a price that reflects both a base policy rate and a premium. It also engages in partial sterilization and reserve accumulation. Its balance sheet is given by

$$
z_{t} R_{t}^{F}+b_{t}^{C}+l_{t}^{C, B}-n w_{t}=m_{t}+R R_{t},
$$

\footnotetext{
${ }^{8}$ Derivations are provided in the working paper version of this article.

${ }^{9}$ Agénor and Pereira da Silva (2017) derive an equation similar to (44) as part of the representative bank's optimization problem by assuming that monitoring costs are endogenous and that monitoring effort is related one-to-one with the probability of repayment. The collateral-loan ratio reflects a moral hazard effect, whereas the cyclical position of the economy reflects the fact that in boom times monitoring is less costly.
} 
where $z_{t} R_{t}^{F}$ denotes international reserves, $b_{t}^{C}$ holdings of government bonds, $m_{t}$ the real supply of cash, and $n w_{t}$ the central bank's net worth.

We consider a managed float regime, in which the central bank also has a target level of reserves, which depends on the degree of exchange rate smoothing and self-insurance motives - captured by a multiple $\phi_{1}^{R}>1$ of the value of imports, $W P_{t}^{F} Y_{t}^{F}$, and a fraction $\phi_{2}^{R} \in(0,1)$ of the net foreign-currency liabilities of the private sector, $L_{t}^{F, B}-B_{t}^{F, P}$ :

$$
R_{t}^{F}=\left(\frac{E_{t}}{E_{t-1}}\right)^{-\varphi_{1}^{R}}\left(R_{t-1}^{F}\right)^{\varphi_{2}^{R}}\left\{\left(\phi_{1}^{R} W P_{t}^{F} Y_{t}^{F}\right)^{\varphi^{R}}\left[\phi_{2}^{R}\left(L_{t}^{F, B}-B_{t}^{F, P}\right)\right]^{1-\varphi^{R}}\right\}^{1-\varphi_{2}^{R}}
$$

where $\varphi^{R} \in(0,1)$ measures the relative importance of the trade motive versus the financial motive, $\varphi_{1}^{R} \geq 0$ the degree to which the central bank leans against movements in the nominal exchange rate, and $\varphi_{2}^{R} \in(0,1)$ the degree of persistence. Thus, as long as $\varphi_{1}^{R}>0$, the central bank buys (sells) reserves to stabilize the exchange rate when it appreciates (depreciates). ${ }^{10}$ In the particular case where $\varphi_{1}^{R}=0$ and $\varphi_{2}^{R}=1$, the stock of reserves remains constant over time and the exchange rate is fully flexible. ${ }^{11}$

The central bank also adjusts its holdings of government bonds in order to sterilize the effects of its buying and selling of international reserves on money supply. Thus, its stock of bonds evolves according to

$$
b_{t}^{C}-\frac{b_{t-1}^{C}}{1+\pi_{t}^{S}}=-\kappa^{F} z_{t} \Delta R_{t}^{F},
$$

where $\kappa^{F} \in(0,1)$ measures the degree of sterilization.

All income received by the central bank is transferred to the government. Thus, changes in the nominal value of the central bank's net worth are given by capital gains from exchange rate depreciation only $\left(\Delta N W_{t}=R_{t}^{F} \Delta E_{t}\right)$. Using this result, taking first differences of (45) in nominal terms and substituting (47) in the resulting expression yields

$$
m_{t}=\frac{m_{t-1}}{1+\pi_{t}^{S}}+\left(1-\kappa^{F}\right) z_{t} \Delta R_{t}^{F}+\left(l_{t}^{C, B}-\frac{l_{t-1}^{C, B}}{1+\pi_{t}^{S}}\right)-\left(R R_{t}-\frac{R R_{t-1}}{1+\pi_{t}^{S}}\right),
$$

which shows that, with full sterilization $\left(\kappa^{F}=1\right)$, changes in the domestic-currency value of foreign-exchange reserves would not affect directly the supply of cash. ${ }^{12}$

\footnotetext{
${ }^{10}$ See for instance Palma and Portugal (2014) for evidence on exchange rate smoothing for Brazil, and Vujanovic (2011) and Fratzscher et al. (2015) for cross-country evidence.

${ }^{11} \mathrm{We}$ also experimented with the expected depreciation rate, $\mathbb{E}_{t} E_{t+1} / E_{t}$, in (46). The results were essentially the same.

${ }^{12}$ This is complete sterilization in a broad sense - as opposed to a narrow sense where the supply of cash remains constant. Indeed, in the present case, changes in foreign reserves could affect the supply of cash indirectly, through changes in $l_{t}^{C, B}$ and $R R_{t}$.
} 
The central bank sets its base policy rate, $i_{t}^{R}$, on the basis of a Taylor-type policy rule:

$$
\frac{1+i_{t}^{R}}{1+\tilde{\imath}^{R}}=\left(\frac{1+i_{t-1}^{R}}{1+\tilde{\imath}^{R}}\right)^{\chi}\left\{\left(\frac{1+\pi_{t}^{S}}{1+\pi^{S, T}}\right)^{\varepsilon_{1}}\left(\frac{Y_{t}^{S}}{\tilde{Y}^{S}}\right)^{\varepsilon_{2}}\right\}^{1-\chi},
$$

where $\tilde{\imath}^{R}$ and $\tilde{Y}^{S}$ are the steady-state values of the policy rate and domestic sales of the final good, $\pi^{S, T} \geq 0$ the central bank's headline inflation target, $\chi \in(0,1)$ a coefficient measuring the degree of interest rate smoothing, and $\varepsilon_{1}, \varepsilon_{2}>0$.

The actual cost of borrowing from the central bank (or, again, the refinance rate), in addition to the base policy rate, a penalty rate, $\theta_{t}^{C, B}$ :

$$
1+i_{t}^{C}=\left(1+i_{t}^{R}\right)\left(1+\theta_{t}^{C, B}\right)
$$

In turn, the penalty rate is positively related to the ratio of central bank borrowing to deposits:

$$
\theta_{t}^{C, B}=\theta_{0}^{C, B}\left(\frac{l_{t}^{C, B}}{d_{t}}\right),
$$

where $\theta_{0}^{C, B}>0$. Thus, the central bank charges a penalty that increases with the amount borrowed. In addition, this amount is scaled by deposits. This helps to capture the fact that, from the perspective of the central bank, the composition of bank liabilities matters when setting borrowing terms. Indeed, in normal times central banks prefer commercial banks to raise deposits to fund their operations rather than borrow from them, so when the ratio $l_{t}^{C, B} / d_{t}$ is too high they raise the cost of refinancing to discourage further borrowing and induce commercial banks to raise deposit rates, thereby improving incentives for households to increase their deposit holdings. In a sense, an $l_{t}^{C, B} / d_{t}$ ratio that is too high creates a stigma effect, which raises funding costs either directly on borrowing from the central bank, as is modeled here, or indirectly through borrowing on the interbank market, as may be the case in practice (see Armantier et al. (2013) and Ennis and Weinberg (2013)).

\subsection{Government}

The government purchases the final good and issues nominal riskless one-period bonds to finance its deficit; it does not borrow abroad. In addition to lump-sum taxes, it also receives the interest income collected by the central bank on its foreign reserves and its loans to commercial banks. It pays interest on the share of government debt held by the 
private sector. Its budget constraint is given by

$$
b_{t}-\frac{b_{t-1}}{1+\pi_{t}^{S}}=G_{t}-T_{t}+\frac{i_{t-1}^{B} b_{t-1}^{P}}{1+\pi_{t}^{S}}-\left(\frac{i_{t-1}^{C} l_{t-1}^{C, B}}{1+\pi_{t}^{S}}+z_{t} i_{t-1}^{W} R_{t-1}^{F}\right),
$$

where $b_{t}=b_{t}^{C}+b_{t}^{P}$ is the stock of government bonds and $G_{t}$ government spending. In what follows the government is assumed to keep its real stock of debt constant $\left(b_{t}=b\right.$, for all $t$ ) and to balance its budget by adjusting lump-sum taxes.

Government purchases are a fraction $\psi \in(0,1)$ of domestic sales of the final good:

$$
G_{t}=\psi Y_{t}^{S}
$$

The production structure and main real and financial flows between agents are summarized in Figure 1.

\section{Equilibrium and Steady State}

In a symmetric equilibrium, $K_{j t}=K_{t}, N_{j t}=N_{t}, Y_{j t}=Y_{t}, P_{j t}^{i}=P_{t}^{i}$, for all $j \in(0,1)$ and $i=D, F$. Equilibrium in the goods market requires that sales on the domestic market be equal to domestic absorption, inclusive of price adjustment costs:

$$
Y_{t}^{S}=C_{t}+G_{t}+I_{t}+\frac{\phi_{D}}{2}\left(\frac{P_{t}^{D}}{P_{t-1}^{D}}-1\right)^{2}\left(\frac{P_{t}^{D}}{P_{t}^{S}}\right) Y_{t}^{D}
$$

with the price of sales on the domestic market, $P_{t}^{S}$, determined through the identity

$$
P_{t} Y_{t}=P_{t}^{S} Y_{t}^{S}+P_{t}^{X} Y_{t}^{X}
$$

Bank loans to IG firms and the capital producer are made in the form of cash. The equilibrium condition of the market for cash is thus given by

$$
m_{t}=m_{t}^{P}+l_{t}
$$

where $m_{t}$ (the supply of cash) is defined in (48).

The equilibrium condition of the housing market is

$$
\bar{H}=H_{t},
$$

which can be solved, using (10), to determine the dynamics of house prices.

Finally, the external budget constraint is given by

$$
W P_{t}^{X} Y_{t}^{X}-W P_{t}^{F} Y_{t}^{F}+i_{t-1}^{W} F_{t-1}+\theta_{t-1}^{F, P} B_{t-1}^{F, P}-\theta_{t-1}^{F, B} L_{t-1}^{F, B}-\Delta F_{t}=0
$$


where $F_{t}=R_{t}^{F}+B_{t}^{F, P}-L_{t}^{F, B}$ is the economy's net foreign asset position.

The steady-state solution of the model is presented in Appendix B. Several of its key features are similar to those described in Agénor et al. (2014). In brief, with a headline inflation target $\pi^{S, T}$ equal to zero, the steady-state inflation rate $\tilde{\pi}^{S}$ is also zero. In addition to standard results (the steady-state value of the marginal cost, for instance, is given by $\left(\theta_{D}-1\right) / \theta_{D}$ and the bond rate by $\left.\tilde{\imath}^{B}=\Lambda^{-1}-1\right)$, the steady-state value of the repayment probability is $\tilde{q}=\left(\kappa \tilde{p}^{H} \bar{H} / \tilde{l}^{I}\right)^{\varphi_{1}}$, whereas $\tilde{\imath}^{C}=\tilde{\imath}^{B}$ (ensuring therefore that banks have no incentives to borrow from the central bank to purchase bonds), $1+\tilde{\imath}^{D}=\left[\zeta^{D} /\left(1+\zeta^{D}\right)\right]\left(1-\tilde{\mu}^{R}\right) \Lambda^{-1}$, and $1+\tilde{\imath}^{L}=\zeta^{L} \Lambda^{-1} /\left(\zeta^{L}-1\right) \tilde{q}$. The base policy rate is thus $1+\tilde{\imath}^{R}=\Lambda^{-1} /\left(1+\tilde{\theta}^{C, B}\right)$. These equations imply that $1+\tilde{\imath}^{D}<1+\tilde{\imath}^{C}$ and, because $\zeta^{L}>1, \tilde{q}\left(1+\tilde{\imath}^{L}\right)>1+\tilde{\imath}^{C}$, which ensures that, given the risk of default, banks have an incentive to borrow from the central bank. From (12), the steady-state stock of foreign bonds held by households is $\tilde{B}^{F, P}=\left[i^{W}-\left(\Lambda^{-1}-1\right)\right] / \theta_{0}^{F, P}\left(1+i^{W}\right)$, which is positive as long as the world risk-free interest rate exceeds the domestic bond rate. The greater the degree of imperfections on world capital markets (the higher $\theta_{0}^{F, P}$ ), the lower are household holdings of foreign bonds.

To analyze the response of the economy to external shocks, we log-linearize the model around a nonstochastic, zero-inflation steady state. The log-linearized equations are summarized in Appendix C.

\section{Parameterization}

To calibrate the model we dwell partly on Agénor et al. (2013, 2014), who themselves rely on a variety of data and sources to characterize a "typical" middle-income country. We also provide here further supporting evidence from the literature for most of our parameter choices. ${ }^{13}$

Parameter values are summarized in Table 1 . The discount factor $\Lambda$ is set at 0.985 , which gives a steady-state annualized real interest rate of 6.1 percent - a fairly common value for studies focusing on developing countries, where real returns tend to be significantly higher than in advanced economies. The intertemporal elasticity of substitution, $\varsigma$, is 0.6 , in line with estimates for middle-income countries (see Agénor and Montiel

\footnotetext{
${ }^{13}$ In addition, for some of the parameters that are deemed critical for this study, sensitivity analysis is reported in the working paper version of this article. This is the case, in particular, for the nature of the monetary policy rule, the degree of exchange rate smoothing, and the intensity of sterilization.
} 
(2015)). The preference parameter for leisure, $\eta_{N}$, is set at 10 , to ensure that in the steady state households devote one third of their time endowment to market activity, consistent with data for Korea and Mexico for instance (see Gertler et al. (2007) and Boz et al. (2015)). A similar share is also a standard normalization for advanced economies (see for instance Christoffel and Schabert (2015)). The parameter for composite monetary assets, $\eta_{x}$, is set at a low value, 0.02 , to capture the common assumption in the literature that their weight in household preferences is negligible (see for instance Coenen et al. (2009) and Christoffel and Schabert (2015)). The same value is used for the housing preference parameter, $\eta_{H}$. The share parameter in the index of money holdings, $\nu$, which corresponds to the relative share of cash in narrow money, is set at 0.35 . This value is consistent with available data for many MICs, where the use of cash remains widespread. The sensitivity of the spread to household foreign bond holdings, $\theta_{0}^{F, P}$, is set at 0.5. This value is consistent with a wide range of estimates for developing countries (see for instance Ferrucci (2003, Table 4)), although most studies are based on sovereign or total external debt as a determinant of (sovereign) spreads. In our setting, it ensures that the steady-state domestic interest rate departs significantly from the (expected) rate of return on foreign assets, as implied by imperfect capital mobility.

The distribution parameter between domestic and imported intermediate goods in the production of the final good, $\Lambda_{D}$, is set at 0.7 , to capture the case of a middle-income economy where imports are about a third of GDP, as in Tomura (2010) and Medina and Roldós (2014). The elasticity of substitution between baskets of domestic and imported composite intermediate goods, $\eta$, is set at 1.5, a fairly standard value used for instance by Cuadra and Nuguer (2014) for Mexico. This implies that these goods are substitutes in the production of the final good. The elasticities of substitution between intermediate domestic goods among themselves, $\theta_{D}$, and imported goods among themselves, $\theta_{F}$, are set to the same value, 10. This value is close to those used for instance by Medina and Soto (2007) for Chile and by Demirel (2010) and Quint and Rabanal (2014); it gives a steady-state estimate of the markup rate, $\theta_{D} /\left(\theta_{D}-1\right)$, equal to 11.1 percent. The instantaneous pass-through coefficient is set at $\mu^{F}=0.3$; this is line with the evidence suggesting a decline in the strength of the pass-through effect in recent years in both industrial and developing countries, possibly as a result of increased integration of global value chains (see Bussière et al. (2014), Devereux and Yetman (2014), and Ahmed et al. (2015)). The price elasticity of exports, $\varkappa$, is set equal to 0.9 , which is close to the value 
of unity used by Gertler et al. (2007) for Korea and consistent with the lower range of estimates for developing countries reported by Imbs and Méjean (2017).

The share of capital in domestic output of intermediate goods, $\alpha$, is set at 0.35 , a fairly standard value. The adjustment cost parameter for prices of domestic intermediate goods, $\phi_{D}$, is set at 74.5 ; this value implies a Calvo-type probability of not adjusting prices of approximately 0.71 percent per period, or equivalently an average period of price fixity of about 3.5 quarters. The latter figure is significantly higher than the numbers reported for Mexico and Turkey by Klenow and Malin (2011) and Özmen and Sevinç (2011) for instance, but it is consistent with the estimate of Carvalho et al. (2014, Table 2 ) for Brazil. The rate of depreciation of private capital, $\delta$, is set equal to 0.02 , a fairly standard value, which implies an annualized depreciation rate of 8.2 percent. In the absence of a well-established benchmark in the literature, the adjustment cost incurred by CG producers for transforming investment into capital, $\Theta_{K}$, is set at 14 to generate an investment path in response to shocks that is of the order of 2 to 3 times more volatile than domestic output, as documented in studies of macroeconomic fluctuations in developing countries (see for instance Neumeyer and Perri (2005) and Agénor and Montiel (2015)). The share of labor costs financed in advance, $\kappa^{W}$, is set at a relatively high value, 0.8, in line with the evidence provided by Cabezon (2014) for instance on the rapid growth of working capital loans in major Latin American countries in recent years.

Regarding commercial banks, the effective collateral-loan ratio, $\kappa$, is set at $0.2-\mathrm{a}$ significantly lower value than the one used by Cavalcanti (2010) for instance but which better captures in our view the difficulty of seizing collateral in most developing countries, due to weak legal systems and inefficient debt enforcement procedures (see Djankov et al. (2008) and Agénor and Pereira da Silva (2013, 2014)). For the elasticities of substitution $\zeta^{D}$ and $\zeta^{L}$, there are no readily available model-based estimates for middleincome countries; accordingly, we set them to the values used by Dib (2010), 2.0 and 4.5 respectively. The elasticities of the repayment probability are set at $\varphi_{1}=0.1$ with respect to the effective collateral-loan ratio and at $\varphi_{2}=0.3$ with respect to deviations in output from its steady state. Parameter $\theta_{0}^{F, B}$, which determines how bank foreign borrowing responds to the differential in the cost of domestic and foreign borrowing, is set at 0.16 ; this value implies that bank foreign liabilities represent about 10 percent of their total liabilities in the initial steady state. 
Regarding the central bank, the required reserve ratio $\mu^{R}$ is set at 0.1 , consistent with the lower range of estimates reported by Montoro and Moreno (2011) for Latin America. Responses of the base policy rate to inflation and output deviations, $\varepsilon_{1}$ and $\varepsilon_{2}$, and the degree of persistence in the central bank's policy response, $\chi$, are set at 2.0, 0.5, and 0.8, respectively. These values are consistent with estimates of Taylor-type rules for MICs, including those of Medina and Soto (2007) for Chile, Palma and Portugal (2014) for Brazil, Armas et al. (2014) for Peru, and Moura and Carvalho (2010) for a broad sample of Latin American countries. The sensitivity of the penalty rate to the bank borrowingrequired reserve ratio, $\theta_{0}^{C, B}$, is set to 0.1 initially. The parameter characterizing the degree of exchange rate smoothing in the foreign reserves targeting rule, $\varphi_{1}^{R}$, is set at 0.5 initially, to reflect a high degree of exchange rate flexibility. The trade motive for self insurance is assumed to be predominant and accordingly the parameter $\varphi^{R}$ is set at 0.8 , whereas the degree of persistence in the rule, $\varphi_{1}^{R}$, is set at 0.8. Given that the model is log-linearized and solved in terms of deviations from the steady state, parameters $\phi_{1}^{R}$ and $\phi_{2}^{R}$ (which relate the targeted stock of foreign reserves to imports and net private foreign-currency liabilities, respectively) are both normalized to unity. The degree of sterilization, $\kappa^{F}$, is set initially at a relatively low value, $0.2 \cdot{ }^{14}$ The share of noninterest government spending in output, $\psi$, is set at 0.2 , a value consistent with the evidence for middle-income countries such as Brazil and South Africa (see Carvalho et al. (2014) and Liu and Seeiso (2011)). Finally, the degree of persistence of the shock to the world risk-free rate, $\rho_{W}$, is set at 0.8 , which implies a reasonably high degree of inertia.

\section{Drop in the World Risk-Free Rate}

To illustrate the impact of external shocks, consider a temporary drop in the world riskfree interest rate by 35 basis points at a quarterly rate, or about 141 basis points at an annual rate. ${ }^{15}$ The magnitude of this shock is relatively large by historical standards but it helps to illustrate well the transmission mechanism.

The results of this experiment are summarized in Figure 2. On impact, the shock lowers both the return on foreign assets and the cost of bank borrowing abroad. Thus,

\footnotetext{
${ }^{14}$ As documented by Aizenman and Glick (2009) and Agénor and Pereira da Silva (2013), the degree of sterilization (as measured by offset coefficients) remains imperfect, even though it has increased in recent years in many MICs.

${ }^{15}$ See for instance Edwards (2010), Byrne and Fiess (2016), Eichengreen and Gupta (2016), and Sarno et al. (2016) for the importance of global factors in explaining capital flows to middle-income countries.
} 
households' holdings of foreign bonds decline, whereas bank foreign liabilities increase; these effects combine to generate an inflow of capital, which leads to a nominal appreciation. The domestic-currency price of imported intermediate goods falls as a result, thereby raising the demand for these goods; because both consumption and investment increase (as explained next), the production of final goods also rises. At the same time, the nominal appreciation lowers inflation (measured in terms of the price of domestic sales) initially, which would normally lead the central bank to reduce the base policy rate. The net effect, however, is an increase in that rate, given the need to mitigate the boom in domestic activity. The inflow of foreign borrowing leads to a reduction in the central bank borrowing-deposit ratio, which in turn lowers the penalty rate; this reduction is large enough to translate into an initial drop in the refinance rate. As a result the loan rate also falls, which further dampens inflation, through a (reverse) cost channel, and promotes investment.

The increase in net private foreign-currency liabilities, combined with higher imports, raise the central bank's desired and (to a smaller extent, given partial adjustment) actual stocks of foreign reserves. With partial sterilization, the accumulation of foreign reserves translates into an expansion of the monetary base. At the same time, because the increase in bank foreign borrowing reduces (at the initial level of investment loans) the amount borrowed from the central bank, the monetary base tends to contract. Given our base parameterization the former effect dominates and this translates into an increase in the supply of cash. Thus, at a given level of consumption, the nominal bond rate must fall to raise the demand for cash and restore market equilibrium. Because expected future inflation increases, the real bond rate unambiguously falls as well. This induces households to reduce savings and increase consumption today.

The fall in the real bond rate also leads to an increase in the demand for housing, which puts upward pressure on real estate prices and increases the value of the collateral that firms can pledge to secure investment loans. Nevertheless, the collateral-loan ratio falls initially, because the reduction in the cost of borrowing stimulates investment significantly. While the reduction in the collateral-loan ratio tends to reduce the repayment probability, the increase in cyclical output tends to increase it; in this experiment, the net effect is indeed positive, whereas the net effect on the loan rate is negative. Thus, as noted earlier, domestic spending increases unambiguously on impact. At the same time, the real appreciation translates into a reduction in exports, which allows domestic sales 
to increase.

During the transition, the increase in the capital stock (which mirrors the investment boom) tends to lower its rental rate and to raise the marginal product of labor. Gross wages tend therefore to increase. At the same time, because the marginal utility of leisure increases with the higher level of current consumption, households tend to reduce their supply of labor. The combination of lower supply of, and higher demand for, labor (associated with the expansion in output) translates into higher wages. Although the fall in the refinance rate (the rate at which intermediate goods producers borrow to finance labor costs) mitigates this initial pressure, the effective wage rate also increases on impact. Over time, the reduction in the rental rate of capital leads during a first phase to lower marginal costs, which magnifies the impact of the initial exchange rate appreciation on inflation, but these effects are eventually reversed.

The results of this experiment show that, consistent with the evidence, external shocks that lead to large inflows of capital (a "sudden flood," in the terminology of Agénor et al. (2014)) generate a domestic boom characterized by a credit expansion, asset price pressures, increases in aggregate demand, an expansion in output, and - over time only, given the initial appreciation - inflationary pressures. Although the boom in domestic activity tends to raise the base policy rate, the drop in inflation (associated with the exchange rate appreciation) tends to reduce it. Given the relative weights of inflation and output deviations in the calibrated Taylor rule, the net effect is an increase in the base policy rate. Nevertheless, the cost of commercial bank borrowing falls because the repayment probability increases (thereby reducing the premium imposed on domestic borrowers) and because the penalty rate imposed by the central bank falls. Essentially, because banks borrow more abroad, they borrow less domestically, which in turns reduces the penalty component of the refinance rate.

To assess the sensitivity of the previous results we conducted several additional experiments with the same shock, involving a stronger response of the penalty rate to the central bank borrowing-deposit ratio, more aggressive exchange rate smoothing, and full sterilization of foreign exchange market intervention. The results are reported in the working paper version of this article. Qualitatively, they are broadly similar to those reported above. 


\section{Countercyclical Reserve Requirements}

In the foregoing discussion it was assumed that the reserve requirement rate, $\mu_{t}^{R}$, is kept constant. As noted earlier, in practice policymakers in MICs have often used reserve requirements as part of a countercyclical toolkit to mitigate credit fluctuations caused by capital inflows. Accordingly, we consider now the case where the central bank implements a countercyclical reserve requirement rule that relates changes in $\mu_{t}^{R}$ endogenously to deviations in the ratio of investment loans to domestic output sales:

$$
\frac{1+\mu_{t}^{R}}{1+\tilde{\mu}^{R}}=\left(\frac{1+\mu_{t-1}^{R}}{1+\tilde{\mu}^{R}}\right)^{\chi_{1}^{R}}\left\{\left(\frac{l_{t}^{I} / Y_{t}^{S}}{\tilde{l}^{I} / \tilde{Y}^{S}}\right)^{\chi_{2}^{R}}\right\}^{1-\chi_{1}^{R}},
$$

where $\chi_{1}^{R} \in(0,1)$ and $\chi_{2}^{R}>0 .{ }^{16}$

At the outset, it is worth noting that in partial equilibrium there is a key difference in the model between an autonomous increase in the base policy rate and an autonomous increase in the reserve requirement rate. On impact, a higher $\mu_{t}^{R}$ lowers the deposit rate (and thus the supply of deposits); all else equal (that is, for a given level of foreign borrowing), the drop in deposits induces banks to borrow more from the central bank. Both effects combine to raise the $l_{t}^{C, B} / d_{t}$ ratio. This leads therefore to an increase in the penalty rate and in the cost of borrowing, $i_{t}^{C}$. Even though in principle $\left(1-\mu_{t}^{R}\right) i_{t}^{C}$ could either increase or fall, should it increase it will be by less than an increase in $i_{t}^{C}$ induced by an autonomous rise in the base policy rate, $i_{t}^{R}$. In fact, if $\left(1-\mu_{t}^{R}\right) i_{t}^{C}$ falls, then $i_{t}^{D}$ would also fall (see (41)), so an increase in the reserve requirement rate would not exacerbate capital flows that are sensitive to domestic deposit rates, in contrast to an increase in the base policy rate. However, in the model capital flows depend on the bond rate, and not the deposit rate. Thus, much depends also on the indirect effects of these two policies, that is, the general equilibrium effects that are captured by the model.

The properties of the model with and without rule (59) are illustrated in Figure 3, in the base case where $\chi_{1}^{R}=0.1$ and $\chi_{2}^{R}=8$; thus, the case considered is that of a fairly aggressive policy with little inertia. On impact, the response of the reserve requirement rate to the initial expansion in credit leads indeed to a drop in bank deposits and to a

\footnotetext{
${ }^{16}$ A forward-looking credit growth rule is discussed in Mimir et al. (2013) and Escudero et al. (2014), whereas Montoro (2011) uses a contemporaneous rule in terms of the level of credit. The working paper version of this article reports results with a credit growth rule; they are qualitatively the same as those reported later on.
} 
slight increase in the central bank borrowing-deposit ratio; as a result, the penalty rate edges up, thereby mitigating the initial drop in the refinance rate and thus the lending rate. This dampens also the initial expansion in credit and investment. The supply of cash expands by less than in the benchmark case, requiring thereby a smaller drop in the bond rate - which in turn weakens incentives to consume today. As a result, aggregate demand also expands by less than in the benchmark case; the endogenous response of the reserve requirement rate is unambiguously countercyclical, in the sense that it mitigates the initial expansion in output, credit, and asset price pressures, even though the policy has more limited effects on inflation and the exchange rate. If anything, the exchange rate appreciates slightly more, because with the domestic bond rate increasing, there is a slight reduction in household holdings of foreign bonds. As a result, domestic inflation falls slightly more on impact — and so does the base policy rate. ${ }^{17}$

\section{Optimal Simple Rules}

In the foregoing analysis we have considered arbitrary values of the parameters characterizing the reserve requirement rule (59). We now consider the case where the central bank is concerned with two objectives, macroeconomic stability and financial stability. Extending the approach described in Agénor et al. (2014), we define macroeconomic (in)stability, $V_{t}^{M}$, in terms of a weighted average of the volatility of inflation deviations and output deviations, and financial (in)stability in terms of two composite measures: a) a narrow index, $V_{t}^{F, N}$, defined as a weighted average of the volatilities of the ratio of investment loans to domestic sales of the final good, $l_{t}^{I} / Y_{t}^{S}$; the ratio of net capital inflows to domestic sales, $\left(L_{t}^{F, B}-B_{t}^{F, P}\right) / Y_{t}^{S}$; and the loan-refinance rate spread, $i_{t}^{L}-i_{t}^{C}$; and $b$ ) a broad index, $V_{t}^{F, B}$, which adds to the variables included in the narrow index the volatility of real asset prices, measured by the volatility of real house prices and the volatility of the real exchange rate. The focus on these variables is consistent with the large body of evidence suggesting that fluctuations in credit, capital flows, interest rate spreads, and asset prices have often been associated with financial instability and financial crises, both in developed and developing countries (see Agénor and Montiel (2015), Taylor (2015), and Caballero (2016)).

\footnotetext{
${ }^{17}$ The working version of this article considers the case where the parameter that characterizes the setting of the penalty rate, $\theta_{0}^{C B}=0$ in (51), and the case where $\theta_{0}^{C B}=0.15$, compared to the baseline value of 0.1 . It also considers different values of $\chi_{2}^{R}$.
} 
For the macroeconomic stability index, we use weights of 0.7 in inflation deviations and 0.3 for output deviations. These weights reflect relatively greater concern with price stability and are consistent with the evidence on central bank preferences in a flexible inflation targeting regime (see for instance Adolfson et al. (2011), Palma and Portugal (2014), Paez-Farrell (2015), and Carney (2017)). For the narrow financial stability index, the weights are $1 / 3$ on each measure whereas for the broad index the weights are 0.3 each for the three variables included in the narrow index, and a weight of 0.05 on each asset price. In the latter case, the weighting ensures that financial variables continue to dominate in the definition of financial stability. This also reflects the fact that the evidence on the behavior of asset prices prior to financial crises appears to be less robust than other variables, especially credit. ${ }^{18}$

In addition, we also specify a composite index of economic stability, $V_{t}$, defined with two sets of weights: first with equal weights of 0.5 attached to each stability objective, and second with a weight of 0.8 for macroeconomic stability and 0.2 for financial stability. Thus, in the first case the central bank shows equal concerns with the two objectives, whereas in the second macroeconomic stability dominates. Formally, the central bank's instantaneous policy loss function can be written as

$$
V_{t}=\left[V_{t}^{M}\left(\sigma_{\pi^{S}}^{2}, \sigma_{Y^{S}}^{2},\right)\right]^{\zeta}\left[V_{t}^{F}\right]^{1-\zeta}
$$

with $\zeta=0.5,0.8$ and $V_{t}^{F}$ equal to either $V_{t}^{F, N}$ or $V_{t}^{F, B}$, defined as ${ }^{19}$

$$
V_{t}^{F, N}=V_{t}^{F, N}\left[\sigma_{l^{I} / Y^{S}}^{2}, \sigma_{\left(L^{F, B}-B^{F, P}\right) Y^{S}}^{2}, \sigma_{i^{L}-i^{D}}^{2}\right], \quad V_{t}^{F, B}=V_{t}^{F, B}\left[V_{t}^{F, N}, \sigma_{p^{H}}^{2}, \sigma_{z}^{2}\right] .
$$

We next consider two cases, for a given value of the persistence parameter $\chi_{1}^{R}=0.1$ in the countercyclical rule (59): $a$ ) the case where the goal of the central bank is to determine the optimal value of $\chi_{2}^{R}$ only so as to minimize the loss function (60); and $b$ ) the case where both $\chi_{2}^{R}$ and the degree of sterilization $\kappa^{F}$ are solved for so as to minimize (60). ${ }^{20}$ A grid step of 1 or 1.5 is used for $\chi_{2}^{R}$ and 0.1 for $\kappa^{F}$, as this is sufficient for our purpose.

\footnotetext{
${ }^{18}$ See again Agénor and Montiel (2015) and Taylor (2015). Changes in these weights have a limited impact on the results. Individual volatility measures are based on the asymptotic (unconditional) variances of the relevant variable.

${ }^{19}$ As discussed by Debortoli et al. (2017) for instance, the macro component of the loss function (60) may represent a parsimonious approximation to social welfare. More generally, function (60) is consistent with studies that take a second-order approximation of household utility in models with financial frictions and find that it differs from the standard case by including a measure of financial conditions. See Andrés et al. (2013) and De Paoli and Paustian (2017) for instance.

${ }^{20}$ In both cases, experiments with a higher value of $\chi_{1}^{R}=0.8$ did not affect the results qualitatively.
} 


\subsection{Reserve Requirements}

A numerical solution to the first problem is illustrated in Figures 4 and 5, in the first case for $\zeta=0.5$ and the second for $\zeta=0.8$, and for both measures of financial stability. The figures show clearly that the relationship between the degree of aggressiveness of the countercyclical reserve rule and economic volatility follows a U-shape pattern. Intuitively, as the policy becomes more aggressive, volatility falls at first, because the policy stabilizes credit, investment and domestic absorption. However, the more aggressive the policy becomes, the more volatile interest rates and deposits become; the volatility in domestic interest rates induces also more volatility in capital flows, and therefore tends to increase financial volatility - so much so that it eventually dominates the gains in terms of reduced volatility in credit and aggregate demand. Thus, there exists an optimal value for $\chi_{2}^{R}$, which is 6 in Figure 4 for both measures of financial stability, when the central bank attaches equal weights to macroeconomic stability and financial stability. By contrast, when the central bank attaches a higher weight to macroeconomic stability $(\zeta=0.8)$, Figure 5 shows that the optimal value of $\chi_{2}^{R}$ is substantially higher, at 11 . The reason is that the countercyclical reserve rule is particularly effective at mitigating fluctuations in investment (which is fully financed by credit) and output. ${ }^{21}$ This result can be seen as providing some support for the use of reserve requirements as a substitute for monetary policy in response to external shocks.

Table 2 reports the asymptotic standard deviations of some key variables. The second column of the table, which corresponds to the case $\zeta=0.5$, shows that the optimal use of reserve requirements improves (compared to the benchmark experiment, whose results are reported in the first column) economic stability by reducing both financial volatility and macroeconomic volatility, although the gains are relatively small in both cases - and despite the fact that volatility in the credit-to-output ratio, investment, and the loan rate all drop by about one third and output volatility (which reflects in part fluctuations in investment) by about a quarter. The benefit of the optimal policy in terms of financial stability stems fundamentally from its stabilizing effect on the credit-to-output ratio; with a greater weight attached to that variable in the financial stability index, the gain associated with the optimal policy would of course be magnified. ${ }^{22}$

\footnotetext{
${ }^{21}$ As can be inferred from Figure 3, the volatility of inflation marginally increases in the presence of the rule. However, this effect is dominated by the reduction in output volatility.

${ }^{22}$ The working paper version of this article also considers how the optimal policy responds to the degree of exchange rate smoothing, $\varphi_{1}^{R}$.
} 


\subsection{Reserve Requirements and Sterilization}

Consider now the case where both $\chi_{2}^{R}$ and $\kappa^{F}$ are solved for optimally. The results of the grid search show that, either in isolation or when combined with reserve requirements, the optimal degree of sterilization is unity. The transmission mechanism when $\kappa^{F}=$ 1 was discussed earlier; to understand why full sterilization is optimal consider the asymptotic variances and minimized loss functions reported in the last two columns of Table 2, which again correspond to the case where $\zeta=0.5$ (similar results are obtained for $\zeta=0.8$ ). The figures presented in the table show indeed that full sterilization is effective in terms of enhancing overall economic stability. By helping to insulate the money supply from the behavior of foreign reserves, used by itself it helps to stabilize movements in policy interest rates and asset prices and, by implication, market interest rates and capital flows. This generates benefits in terms of financial stability and, to a lesser extent, macroeconomic stability. When combined with an optimal use of reserve requirements, the benefits are magnified. Thus, the combination of policy instruments is preferable to the use of a single macroprudential tool; in that sense, the instruments are complements. In terms of our overall index of financial stability, the benefit of optimal (full) sterilization results solely from its effect on reducing private capital flow volatility. This implies that the marginal contribution of sterilization is higher in terms of macroeconomic stability than it is with respect to financial stability. Moreover, when the degree of sterilization $\kappa^{F}$ increases from its initial value of 0.2 to its optimal value of 1.0 , the countercyclical reserve requirement rule becomes less aggressive; $\chi_{2}^{R}$ falls from 6 to 4.5 , implying that the two instruments are partial substitutes at the margin.

\section{Concluding Remarks}

Central banks in middle-income countries are often confronted with the dilemma of achieving several competing objectives with limited policy instruments. In particular, in response to large capital inflows, they may want to target a stable exchange rate and low inflation, as well as curb credit growth. However, although by raising the policy interest rate to tighten monetary policy the price stability objective may be met, the interest rate increase may attract additional capital inflows and magnify the appreciation of the domestic currency. As a result, central banks have often used reserve requirements as a substitute to monetary policy. Before the global financial crisis, the use of 
reserve requirements was indeed often motivated by monetary policy or microprudential objectives. More recently there has been a formal recognition that reserve requirements can also help to address concerns arising from the procyclicality of the financial system. Accordingly, there has been renewed thinking about the role of reserve requirements as a macroprudential instrument.

In this paper, the performance of a countercyclical reserve requirement rule was studied in a dynamic stochastic model of a small open economy with financial frictions, imperfect capital mobility, a managed float regime, and sterilized foreign exchange market intervention. Deposits and central bank liquidity were also assumed to be imperfect substitutes as sources of bank funding. This was captured by assuming that the rate at which banks can borrow from the monetary authority incorporates a premium (above and beyond a base policy rate), which depends on the ratio of central bank borrowing to deposits.

The model was calibrated and used to study the effects of a temporary drop in the world risk-free interest rate. Consistent with the stylized facts, the simulations showed that this shock triggers an expansion in domestic credit and activity, asset price pressures, and a real appreciation. We also showed that a credit-based reserve requirement rule helps to mitigate both macroeconomic and financial volatility, with the latter defined in terms of a narrow measure based on the credit-to-output ratio, the ratio of capital flows to output, and interest rate spreads, as well as a broader measure that includes also real asset prices. An optimal rule, based on minimizing a composite measure of economic volatility (a loss function combining measures of both macroeconomic and financial volatility), was also derived. Unlike other studies, such as Glocker and Towbin (2012), the relationship between the degree of aggressiveness of the countercyclical reserve rule and economic volatility was shown to be nonmonotonic. At first, as the policy becomes more aggressive, volatility falls because it stabilizes credit, investment and domestic absorption. As the policy becomes more aggressive, it magnifies volatility in interest rates and bank deposits; in turn, higher volatility in domestic interest rates induces more volatility in capital flows, and therefore tends to increase financial volatility — so much so that it eventually dominates the gains in terms of reduced volatility in credit growth and aggregate demand.

We also showed that if the quasi-fiscal costs of sterilization are abstracted from it is optimal to fully sterilize, even when a countercyclical reserve requirements rule is in 
place. In that sense, the two instruments are complements. In addition, greater reliance on sterilization implies a less aggressive optimal reserve requirements rule, which implies that the two instruments are partial substitutes at the margin.

Our analysis provides important lessons for policymakers in middle-income countries confronted with the dilemmas associated with external financial shocks. Our results support the view that to dampen the potentially destabilizing effects of large capital flows on asset prices and credit markets, countercyclical reserve requirements can be highly effective. Raising interest rates to contain aggregate demand pressures during episodes of sudden floods can be self-defeating, as this may induce more capital inflows; under such circumstances raising reserve requirements - an instrument with which central banks in MICs are very familiar with and can be deployed quickly - may help to contain not only aggregate demand but also credit growth, a key determinant of systemic financial risks. This is an important message in the context of the ongoing debate about the choice and implementation of macroprudential instruments. 


\section{References}

Adolfson, Malin, Stefan Laséen, Jesper Lindé, and Lars E. O. Svensson, "Optimal Monetary Policy in an Operational Medium-Sized DSGE Model," Journal of Money, Credit and Banking, 43 (October 2011), 1287-331.

Agénor, Pierre-Richard, Capital-Market Imperfections and the Macroeconomic Dynamics of Small Indebted Economies, Princeton Study in International Finance No. 82 (June 1997).

Agénor, Pierre-Richard, Koray Alper, and Luiz Pereira da Silva, "Capital Regulation, Monetary Policy and Financial Stability," Int. J. of Central Banking, 9 (September 2013), 193-238.

—- "Sudden Floods, Macroprudential Regulation, and Stability in an Open Economy," J. Int. Money Finance, 48 (November 2014), 68-100.

Agénor, Pierre-Richard, and Peter J. Montiel, Development Macroeconomics, 4rd ed., Princeton University Press (Princeton, New Jersey: 2015).

Agénor, Pierre-Richard, and Luiz Pereira da Silva, Inflation Targeting and Financial Stability, Inter-American Development Bank (Washington DC: 2013).

—_, "Macroprudential Regulation and the Monetary Transmission Mechanism," J. Financial Stab., 13 (August 2014), 44-63.

—_ "Cyclically Adjusted Provisions and Financial Stability," J. Financial Stab., 28 (February 2017), 143-62.

Ahmed, Swarnali, Maximiliano Appendino, and Michele Ruta, "Depreciations without Exports? Global Value Chains and the Exchange Rate Elasticity of Exports." Policy Research Working Paper No. 7390, World Bank (August 2015).

Aizenman, Joshua, and Reuven Glick, "Sterilization, Monetary Policy, and Global Financial Integration," Rev. Int. Econ., 17 (September 2009), 777-801.

Andrés, Javier, Oscar Arce, and Carlos Thomas, "Collateral Constraints, Banking Competition and Optimal Monetary Policy," J. Money, Credit Banking, 45 (December 2013), 87-125.

Armantier, Olivier, Eric Ghysels, Asani Sarkar, and Jeffrey Shrader, "Discount Window Stigma during the 2007-2008 Financial Crisis," Staff Report No. 483, Federal Reserve Bank of New York (revised, September 2013).

Armas, Adrián, Paul Castillo, and Marco Vega, "Inflation Targeting and Quantitative Tightening: Effects of Reserve Requirements in Peru," Working Paper No. 499, InterAmerican Development Bank (April 2014).

Barroso, João B., Rodrigo B. Gonzalez, and Bernardus F. Van Doornik, "Credit Supply Responses to Reserve Requirement: Loan-Level Evidence from Macroprudential Policy," Working Paper No. 674, Bank for International Settlements (November 2017).

Basel Committee on Banking Supervision, "Basel III: A Global Regulatory Framework for more Resilient Banks and Banking Systems," Report No. 189 (revised, June 2011).

—_ "Basel III: The Liquidity Coverage Ratio and Liquidity Risk Monitoring Tools," Report No. 238 (January 2013).

Boz, Emine, C. Borda Durdu, and Nan Li, "Emerging Market Business Cycles: The Role of Labor Market Frictions," J. Money, Credit Banking, 47 (February 2015), 31-72.

Bussière, Matthieu, Simona Delle Chiaie, and Tuomas A. Peltonen, "Exchange Rate PassThrough in the Global Economy," IMF Econ. Rev., 62 (April 2014), 146-78. 
Byrne, Joseph P., and Norbert Fiess, "International Capital Flows to Emerging Markets: National and Global Determinants," J. of Int. Money Finance, 61 (March 2016), 82-100.

Caballero, Julián A., "Do Surges in International Capital Inflows Influence the Likelihood of Banking Crises?," Economic Journal, 126 (March 2016), 281-316.

Cabezon, Ezequiel, "Working Capital, Financial Frictions and Monetary Policy in Brazil," unpublished, University of North Carolina at Chapel Hill (November 2014).

Carney, Mark, "Lambda," speech at the London School of Economics, available online (January 2017).

Carvalho, Fabia A. de, Marcos R. Castro, and Silvio M. A. Costa, "Traditional and Matterof-Fact Financial Frictions in a DSGE Model for Brazil: The Role of Macroprudential Instruments and Monetary policy," Working Paper No 460, Bank for International Settlements (September 2014).

Cavalcanti, Marco Antonio F. H., "Credit Market Imperfections and the Power of the Financial Accelerator: A Theoretical and Empirical Investigation," J. Macroecon., 32 (March 2010), 118-44.

Cerutti, Eugenio, Stijn Claessens, and Luc Laeven, "The Use and Effectiveness of Macroprudential Policies: New Evidence," Journal of Financial Stability, 28 (February 2017), 203-24.

Chang, Roberto, "Inflation Targeting, Reserves Accumulation, and Exchange Rate Management in Latin America," Working Paper No. 487, Central Bank of Colombia (March 2008).

Christoffel, Kai, and Andreas Schabert, "Interest Rates, Money, and Banks in an Estimated Euro Area Model," Working Paper No. 1791, European Central Bank (May 2015).

Coenen, Günter, Giovanni Lombardo, Frank Smets, and Roland Straub, "International Transmission and Monetary Policy Cooperation," in International Dimensions of Monetary Policy, ed. by Jordi Galí and Mark Gertler, University of Chicago Press (Chicago, Ill.: 2009).

Committee on International Economic Policy and Reform, "Banks and Cross-Border Capital Flows: Policy Challenges and Regulatory Responses," Brookings Institution (Washington DC: 2012).

Cuadra, Gabriel, and Victoria Nuguer, "Risky Banks and Macroprudential Policy for Emerging Economies," unpublished, Bank of Mexico (December 2014).

Daude, Christian, Eduardo Levy Yeyati, and Arne J. Nagengast, "On the Effectiveness of Exchange Rate Interventions in Emerging Markets," J. Int. Money Finance, (June 2016), 239-61.

Debortoli, Davide, Jinill Kim, Jesper Lindé, and Ricardo Nunes, "Designing a Simple Loss Function for Central Banks: Does a Dual Mandate Make Sense?," Working Paper No. 17/163, International Monetary Fund (July 2017).

Demirel, Ufuk D., "Macroeconomic Stabilization in Developing Economies: Are Optimal Policies Procyclical?," European Econ. Rev., 54 (April 2010), 409-28.

De Paoli, Bianca, and Matthias Paustian, "Coordinating Monetary and Macroprudential Policies," J. Money, Credit Banking, 49 (March 2017), 319-49.

Devereux, Michael B., and James Yetman, "Globalisation, Pass-through and the Optimal Policy Response to Exchange Rates," J. Int. Money Finance, 49 (December 2014), 104-28. 
Dib, Ali, "Banks, Credit Market Frictions, and Business Cycles," Working Paper No. 201024, Bank of Canada (October 2010).

Djankov, Simeon, Oliver Hart, Caralee McLiesh, and Andrei Shleifer, "Debt Enforcement around the World," J. Political Econ., 116 (December 2008), 1105-49.

Edwards, Sebastian, "The International Transmission of Interest Rate Shocks: The Federal Reserve and Emerging Markets in Latin America and Asia," J. Int. Money Finance, 29 (June 2010), 685-703.

Eichengreen, Barry, and Poonam Gupta, "Managing Sudden Stops," Policy Research Working Paper No. 7639, World Bank (April 2016).

Ennis, Huberto M., and John A.Weinberg, "Over-the-counter Loans, Adverse Selection, and Stigma in the Interbank Market," Rev. Econ. Dyn., 16 (October 2013), 601-16.

Escudero, Matias, Martin Gonzalez-Rozada, and Martin Sola, "Towards a 'New' Inflation Targeting Framework: The Case of Uruguay," unpublished, Northwestern University (January 2014).

Federico, Pablo, Carlos A. Vegh, and Guillermo Vuletin, "Reserve Requirement Policy over the Business Cycle," Working Paper No. 20612, National Bureau of Economic Research (October 2014).

Fendoglu, Salih, "Credit Cycles and Capital Flows: Effectiveness of the Macroprudential Policy Framework in Emerging Market Economies," Journal of Banking and Finance, 79 (June 2017), 110-28.

Ferrucci, Gianluigi, "Empirical Determinants of Emerging Market Economies' Sovereign Bond Spreads," Working Paper No. 205, Bank of England (November 2003).

Fratzscher, Marcel, Oliver Gloede, Lukas Menkhoff, Lucio Sarno, Tobias Stöhr, "When is Foreign Exchange Intervention Effective? Evidence from 33 Countries," unpublished, Kiel Institute for the World Economy (February 2015).

Gabaix, Xavier, and Matteo Maggiori, "International Liquidity and Exchange Rate Dynamics," Discussion Paper No. 9842, Centre for Economic Policy Research (February 2014).

Gertler, Mark, Simon Gilchrist, and Fabio M. Natalucci, "External Constraints on Monetary Policy and the Financial Accelerator," J. Money, Credit Banking, 39 (March 2007), 295330.

Glocker, Christian, and Pascal Towbin, "Reserve Requirements for Price and Financial Stability: When are they Effective?," Int. J. Central Banking, 8 (March 2012), 65-114.

—_, "Reserve Requirements as a Macroprudential Instrument: Empirical Evidence from Brazil," J. of Macroecon., 44 (June 2015), 158-76.

Herrmann, Sabine, and Dubravko Mihaljek, "The Determinants of Cross-Border Bank Flows to Emerging Markets: New Empirical Evidence on the Spread of Financial Crises," Economics of Transition, 21 (July 2013) 1-27.

Hoffmann, Andreas, and Axel Löffler, "Low Interest Rate Policy and the Use of Reserve Requirements in Emerging Markets," Quarterly Rev. Econ. Finance, 54 (August 2014), 307-14.

Hoggarth, Glenn, Lavan Mahadeva, and Jeremy Martin, "Understanding International Bank Capital Flows during the recent Financial Crisis," Financial Stability Paper No. 8, Bank of England (September 2010).

Imbs, Jean, and Isabelle Méjean, "Trade Elasticities," Review of International Economics (May 2017), 383-402. 
Klenow, Peter J., and Benjamin A. Malin, "Microeconomic Evidence on Price-Setting," in Handbook of Monetary Economics, ed. by Benjamin Friedman and Michael Woodford, Vol. 3A, Elsevier (New York: 2011).

Lartey, Emmanuel K., "Financial Openness, Nontradable Inflation and Optimal Monetary Policy," Econ. Letters, 17 (December 2012), 782-85.

Liu, Guangling, and Nkhahle E. Seeiso, "Business Cycle and Bank Capital Regulation: Basel II Procyclicality," Working Paper No. 221, University of Stellenbosch (June 2011).

Liu, Zheng, and Mark M. Spiegel, "Monetary Policy Regimes and Capital Account Restrictions in a Small Open Economy," Working Paper No. 2013-33, Federal Reserve Bank of San Francisco (July 2014).

Medina, Juan Pablo, and Jorge Roldós, "Monetary and Macroprudential Policies to Manage Capital Flows," Working Paper No. 14/30, International Monetary Fund (February 2014).

Medina, Juan Pablo, and Claudio Soto, "The Chilean Business Cycles through the Lens of a Stochastic General Equilibrium Model," Working Paper No. 457, Central Bank of Chile (December 2007).

Mimir, Yasin, Enes Sunel, and Temel Taskin, "Required Reserves as a Credit Policy Tool," B.E. J. of Macroecon., 13 (January 2013), 823-80.

Montoro, Carlos, "Assessing the Role of Reserve Requirements under Financial Frictions," unpublished, Bank for International Settlements (March 2011).

Montoro, Carlos, and Ramon Moreno, "The Use of Reserve Requirements as a Policy Instrument in Latin America," BIS Quarterly Rev. (March 2011), 53-65.

Moura, Marcelo L., and Alexandre de Carvalho, "What can Taylor Rules Say about Monetary Policy in Latin America?," J. of Macroecon., 32 (March 2010), 392-404.

Neumeyer, Pablo A., and Fabrizio Perri, "Business Cycles in Emerging Economies: The Role of Interest Rates," J. Monetary Econ., 52 (March 2005), 345-80.

Özmen, M. Utku, and Orhun Sevinç, "Price Rigidity in Turkey: Evidence from Micro Data," Working Paper No. 11/25, Central Bank of Turkey (November 2011).

Paez-Farrell, Juan, "Taylor Rules, Central Bank Preferences and Inflation Targeting," Working Paper No. 2015-23, University of Sheffield (November 2015).

Palma, Andreza A., and Marcelo S. Portugal, "Preferences of the Central Bank of Brazil under the Inflation Targeting Regime: Estimation using a DSGE Model for a Small Open Economy," J. Policy Modeling, 36 (September 2014), 824-39.

Quint, Dominic, and Pau Rabanal, "Monetary and Macroprudential Policy in an Estimated DSGE Model of the Euro Area," Int. J. Central Banking, 10 (June 2014), 169-236.

Reinhardt, Dennis, and Steven J. Riddiough, "The Two Faces of Cross-Border Banking Flows: An Investigation into the Links between Global Risk, Arms-Length Funding and Internal Capital Markets," Working Paper No. 498, Bank of England (April 2014).

Robitaille, Patrice, "Liquidity and Reserve Requirements in Brazil," Working Paper No. 1021, International Finance Discussion Papers, Federal Reserve Board (June 2011).

Sarno, Lucio, Ilias Tsiakas, and Barbara Ulloa, "What Drives International Portfolio Flows?," J. Int. Money Finance, 60 (February 2016), 53-72.

Shi, Kang, and Juanyi Xu, "Intermediate Goods Trade and Exchange Rate Pass-through," J. Macroecon., 32 (June 2010), 571-83.

Taylor, Alan M., "Credit, Financial Stability, and the Macroeconomy," Working Paper No. 21039, National Bureau of Economic Research (March 2015). 
Tomura, Hajime, "International Capital Flows and Expectation-Driven Boom-Bust Cycles in the Housing Market," J. Econ. Dyn. Control, 34 (October 2010), 1993-2009.

Tovar, Camilo E., Mercedes Garcia-Escribano, and Mercedes Vera Martin, "Credit Growth and the Effectiveness of Reserve Requirements and other Macroprudential Instruments in Latin America," Working Paper No. 12/143, International Monetary Fund (June 2012).

Vargas, Hernando, Carlos Varela, Yanneth R. Betancourt, and Norberto Rodriguez, "Effects of Reserve Requirements in an Inflation Targeting Regime: The Case of Colombia," Working Paper No. 587, Central Bank of Colombia (March 2010).

Vujanovic, Petar, "Understanding the Recent Surge in the Accumulation of International Reserves," Working Paper No. 866, OECD Economics Department (May 2011). 
Table 1

Benchmark Parameterization: Key Parameter Values

\begin{tabular}{|c|c|c|}
\hline Parameter & Value & Description \\
\hline \multicolumn{3}{|l|}{ Household } \\
\hline$\Lambda$ & 0.985 & Discount factor \\
\hline$\varsigma$ & 0.6 & Elasticity of intertemporal substitution \\
\hline$\eta_{N}$ & 10.0 & Preference parameter for leisure \\
\hline$\eta_{x}$ & 0.02 & Preference parameter for money holdings \\
\hline$\eta_{H}$ & 0.02 & Preference parameter for housing \\
\hline$\nu$ & 0.35 & Share parameter in index of money holdings \\
\hline$\theta_{0}^{F, P}$ & 0.5 & Sensitivity of premium, household foreign bonds \\
\hline \multicolumn{3}{|l|}{ Production } \\
\hline$\Lambda_{D}$ & 0.7 & distribution parameter, final good \\
\hline$\eta$ & 1.5 & Elasticity of substitution, baskets of intermediate goods \\
\hline$\mu^{F}$ & 0.3 & Exchange rate pass-through, imported goods \\
\hline$\varkappa$ & 0.9 & Price elasticity of exports \\
\hline$\theta_{D}, \theta_{F}$ & 10.0 & Elasticity of demand, intermediate goods \\
\hline$\alpha$ & 0.35 & Share of capital, domestic intermediate goods \\
\hline$\phi_{D}$ & 74.5 & Adjustment cost parameter, domestic IG prices \\
\hline$\delta$ & 0.02 & Depreciation rate of capital \\
\hline$\Theta_{K}$ & 14 & Adjustment cost parameter, investment \\
\hline$\kappa^{W}$ & 0.8 & Share of labor costs financed in advance \\
\hline \multicolumn{3}{|c|}{ Commercial banks } \\
\hline$\kappa$ & 0.2 & Effective collateral-loan ratio \\
\hline$\varphi_{1}$ & 0.1 & Elasticity of repayment probability, collateral \\
\hline$\varphi_{2}$ & 0.3 & Elasticity of repayment probability, cyclical output \\
\hline$\zeta^{D}$ & 2.0 & Elasticity of substitution, deposits \\
\hline$\zeta^{L}$ & 4.5 & Elasticity of substitution, loans to CG producers \\
\hline$\theta_{0}^{F, B}$ & 0.16 & Sensitivity of premium, bank foreign borrowing \\
\hline \multicolumn{3}{|l|}{ Central bank } \\
\hline$\mu^{R}$ & 0.1 & Reserve requirement rate \\
\hline$\chi$ & 0.8 & Degree of interest rate smoothing \\
\hline$\varepsilon_{1}$ & 2.0 & Response of base policy rate to inflation deviations \\
\hline$\varepsilon_{2}$ & 0.5 & Response of base policy rate to output deviations \\
\hline$\theta_{0}^{C, B}$ & 0.1 & Sensitivity of penalty rate to borrowing-deposit ratio \\
\hline$\varphi_{1}^{R}$ & 0.5 & Exchange rate smoothing parameter, foreign reserves rule \\
\hline$\varphi_{2}^{R}$ & 0.8 & Persistence parameter, foreign reserves rule \\
\hline$\varphi^{R}$ & 0.8 & Relative weight on trade motive, foreign reserves rule \\
\hline$\kappa^{F}$ & 0.2 & Sterilization coefficient \\
\hline$\chi_{1}^{R}$ & 0.1 & Persistence coefficient, reserve requirement rule \\
\hline \multicolumn{3}{|l|}{ Government } \\
\hline$\psi$ & 0.2 & Share of government spending in domestic output sales \\
\hline \multicolumn{3}{|c|}{ World interest rate } \\
\hline$\rho_{W}$ & 0.8 & Persistence parameter, shock to world risk-free rate \\
\hline
\end{tabular}


Table 2

Asymptotic Standard Deviations of Key Variables and Central Bank Loss Function under Alternative Policy Regimes

\begin{tabular}{lcccc}
\hline \hline & $\begin{array}{c}\text { Core } \\
\text { experiment }\end{array}$ & $\begin{array}{c}\text { Optimal required } \\
\text { Reserve ratio }\end{array}$ & $\begin{array}{c}\text { Optimal degree } \\
\text { of sterilization }\end{array}$ & $\begin{array}{c}\text { Optimal } \\
\text { combination }\end{array}$ \\
\hline \hline \multicolumn{1}{c}{ Real variables } & & & & \\
Domestic sales, final good & 0.0029 & 0.0023 & 0.0028 & 0.0022 \\
Employment & 0.0024 & 0.0031 & 0.0024 & 0.0031 \\
Investment & 0.0064 & 0.0048 & 0.0063 & 0.0047 \\
Consumption & 0.0009 & 0.0009 & 0.0009 & 0.0009 \\
Real exchange rate & 0.0075 & 0.0079 & 0.0076 & 0.0079 \\
Exports & 0.0068 & 0.0071 & 0.0068 & 0.0071 \\
& & & & \\
\multicolumn{1}{c}{ Price inflation } & 0.0009 & 0.0010 & 0.0008 & 0.0009 \\
$\quad$ Financial variables & & & & \\
Base policy rate & 0.0017 & 0.0017 & 0.0014 & 0.0014 \\
Refinance rate & 0.0006 & 0.0007 & 0.0005 & 0.0005 \\
Loan rate & 0.0009 & 0.0007 & 0.0008 & 0.0007 \\
Loan-refinance rate spread & 0.0004 & 0.0004 & 0.0004 & 0.0003 \\
Government bond rate & 0.0006 & 0.0007 & 0.0005 & 0.0006 \\
Real house prices & 0.0016 & 0.0015 & 0.0015 & 0.0014 \\
Repayment probability & 0.0004 & 0.0004 & 0.0004 & 0.0003 \\
Loan-to-output ratio & 0.0035 & 0.0026 & 0.0035 & 0.0026 \\
Bank foreign borrowing & 0.6084 & 0.6224 & 0.5980 & 0.6080 \\
Private capital inflows & 0.2922 & 0.2934 & 0.2877 & 0.2879 \\
Official foreign reserves & 0.0497 & 0.0497 & 0.0488 & 0.0488 \\
$\quad$ Loss function & & & & \\
Macro component & 0.0015 & 0.0014 & 0.0014 & 0.0013 \\
Financial component & 0.0978 & 0.0977 & 0.0962 & 0.0960 \\
Composite & 0.0496 & 0.0495 & 0.0488 & 0.0487 \\
\hline \hline
\end{tabular}

Note: In the core experiment and the optimal reserve requirement experiment (columns 1 and 2) the sterilization coefficient is set equal to its benchmark value of $\kappa^{F}=0.2$. In the last two experiments, $\kappa^{F}=1$. In addition, in the third experiment, the required reserve ratio is set at its benchmark value of $\mu^{R}=0.1$. The optimal value of $\chi_{2}^{R}$ is 6 in the second column and 4.5 in the fourth column. All results are based on equal weights for macroeconomic stability and financial stability in the composite loss function. 
Figure 1

Model Structure

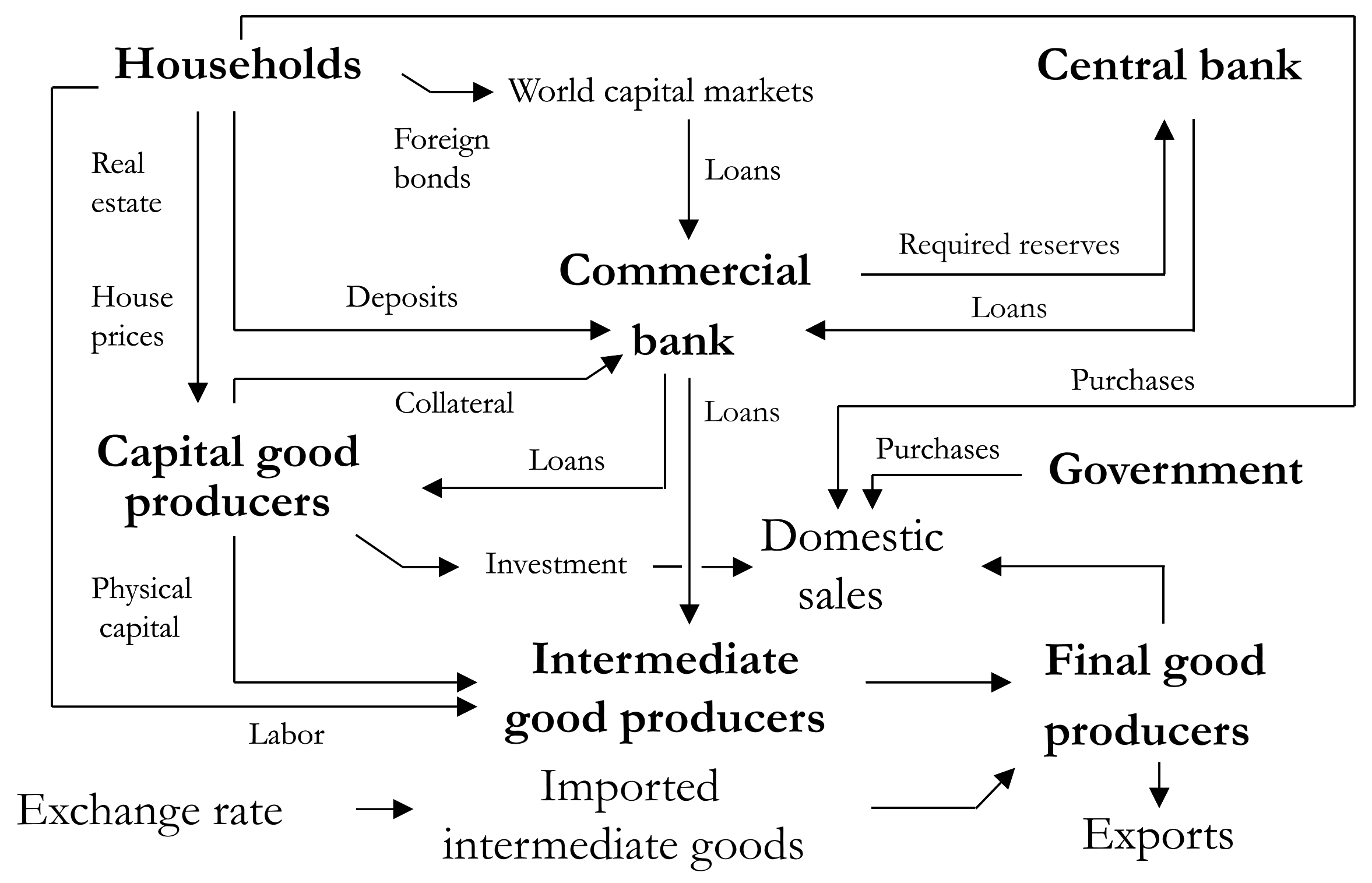


Figure 2

Experiment: Transitory Drop in the World Risk-Free interest Rate Benchmark Case and Case of Perfect Substitution between Bank Domestic Funding Sources

(Deviations from steady state)
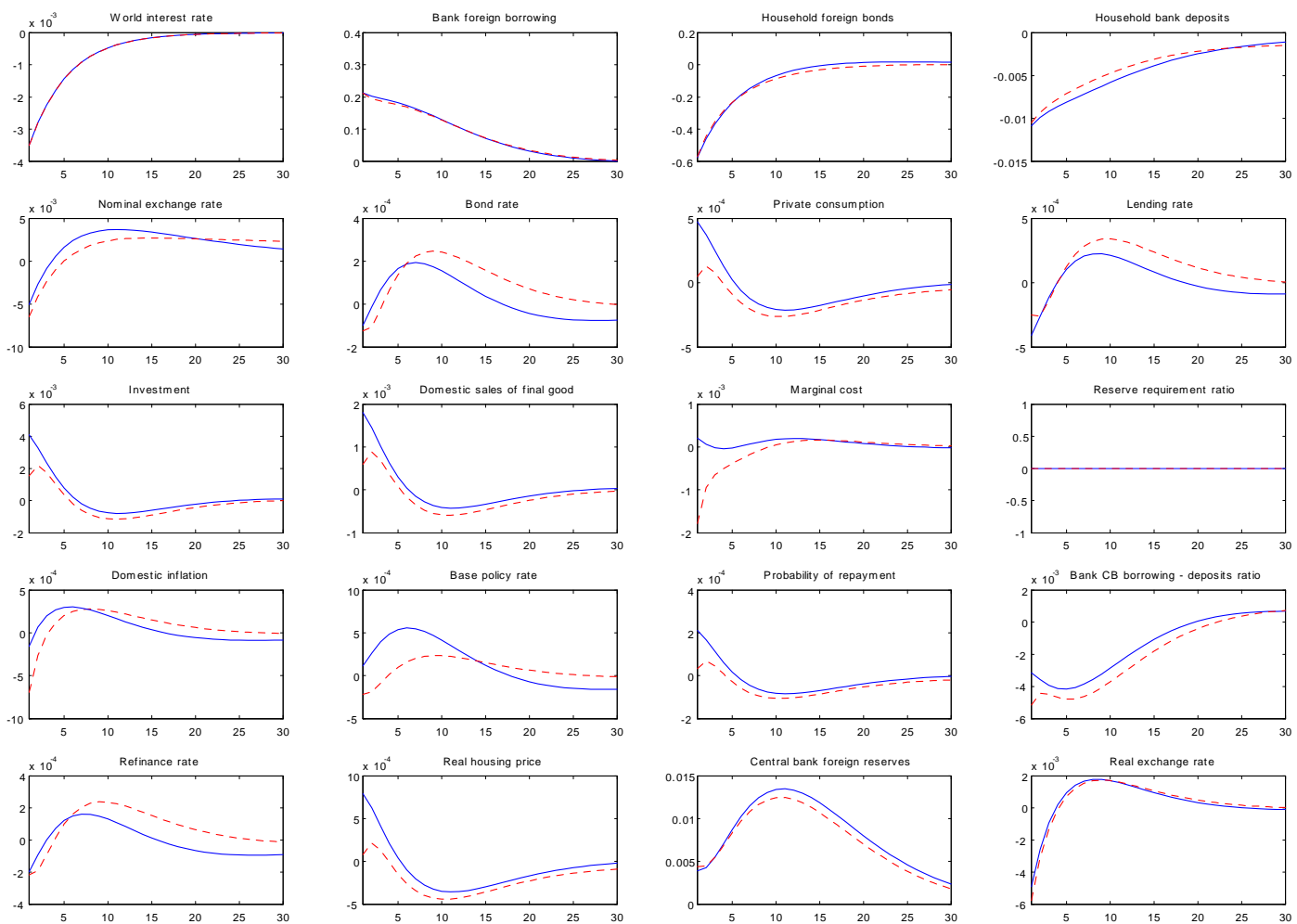

Benchmark --- Zero tor thetaCB

Note: Interest rates, inflation rate and the repayment probability are measured in absolute deviations, that is, in the relevant graphs a value of 0.05 for these variables corresponds to a 5 percentage point deviation in absolute terms. The real exchange rate is defined as the ratio of the nominal exchange rate divided by the price of domestically-produced final goods sold on the domestic market. 
Figure 3

Experiment: Transitory Drop in the World Risk-Free interest Rate Exogenous and Endogenous Countercyclical Reserve Requirement Rule, $\chi_{1}^{R}=0.1, \chi_{2}^{R}=8, \theta_{0}^{C B}=0.1$

(Deviations from steady state)
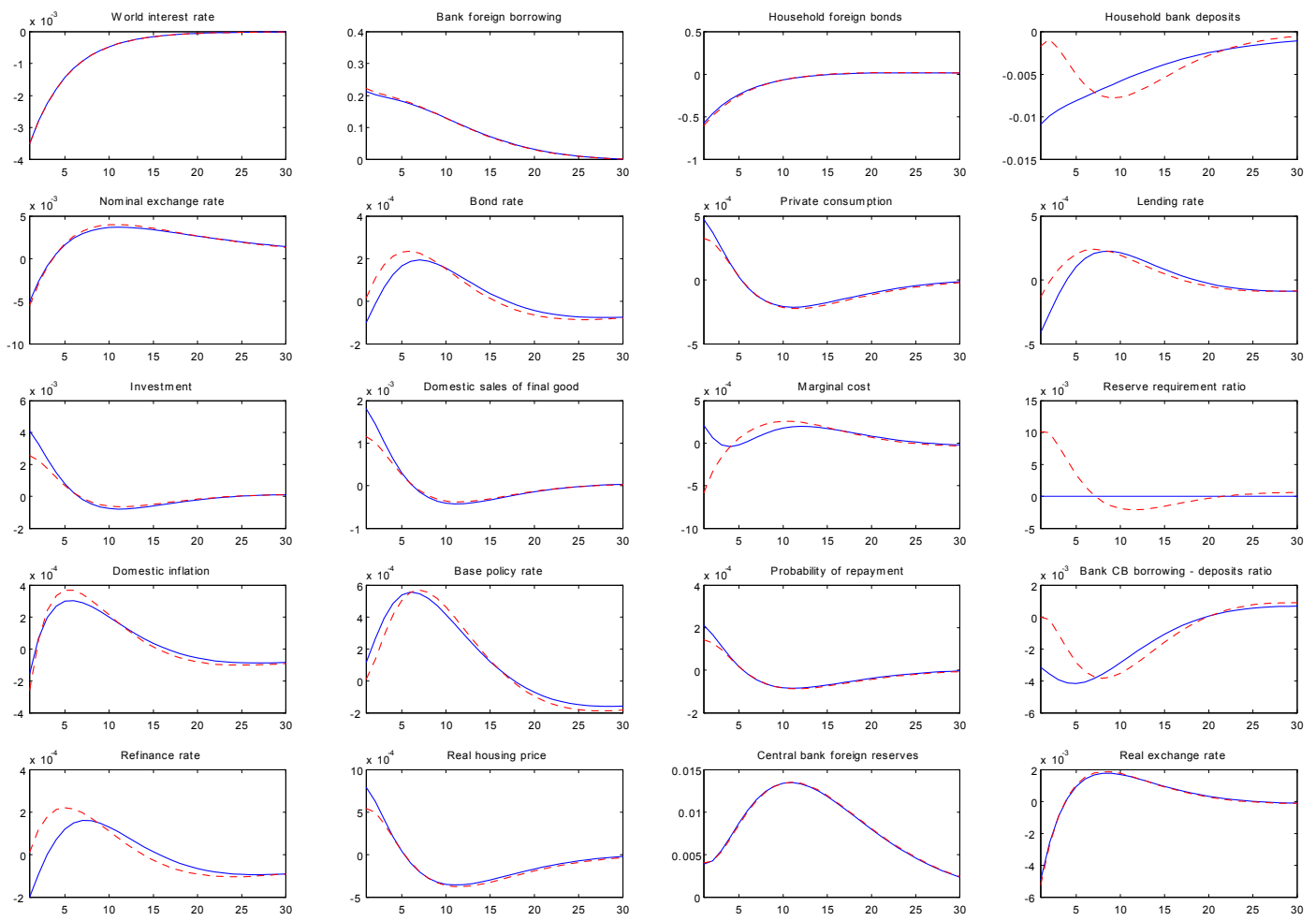

Benchmark --- Chi R1=0.1 Chi R2=8

Note: Interest rates, inflation rate and the repayment probability are measured in absolute deviations, that is, in the relevant graphs a value of 0.05 for these variables corresponds to a 5 percentage point deviation in absolute terms. The real exchange rate is defined as the ratio of the nominal exchange rate divided by the price of domestically-produced final goods sold on the domestic market. 
Figure 4

Index of Economic Volatility and Aggressiveness of the Countercyclical of the Reserve Requirement Rule Equal Weights of 0.5 to Macro and Financial Volatility
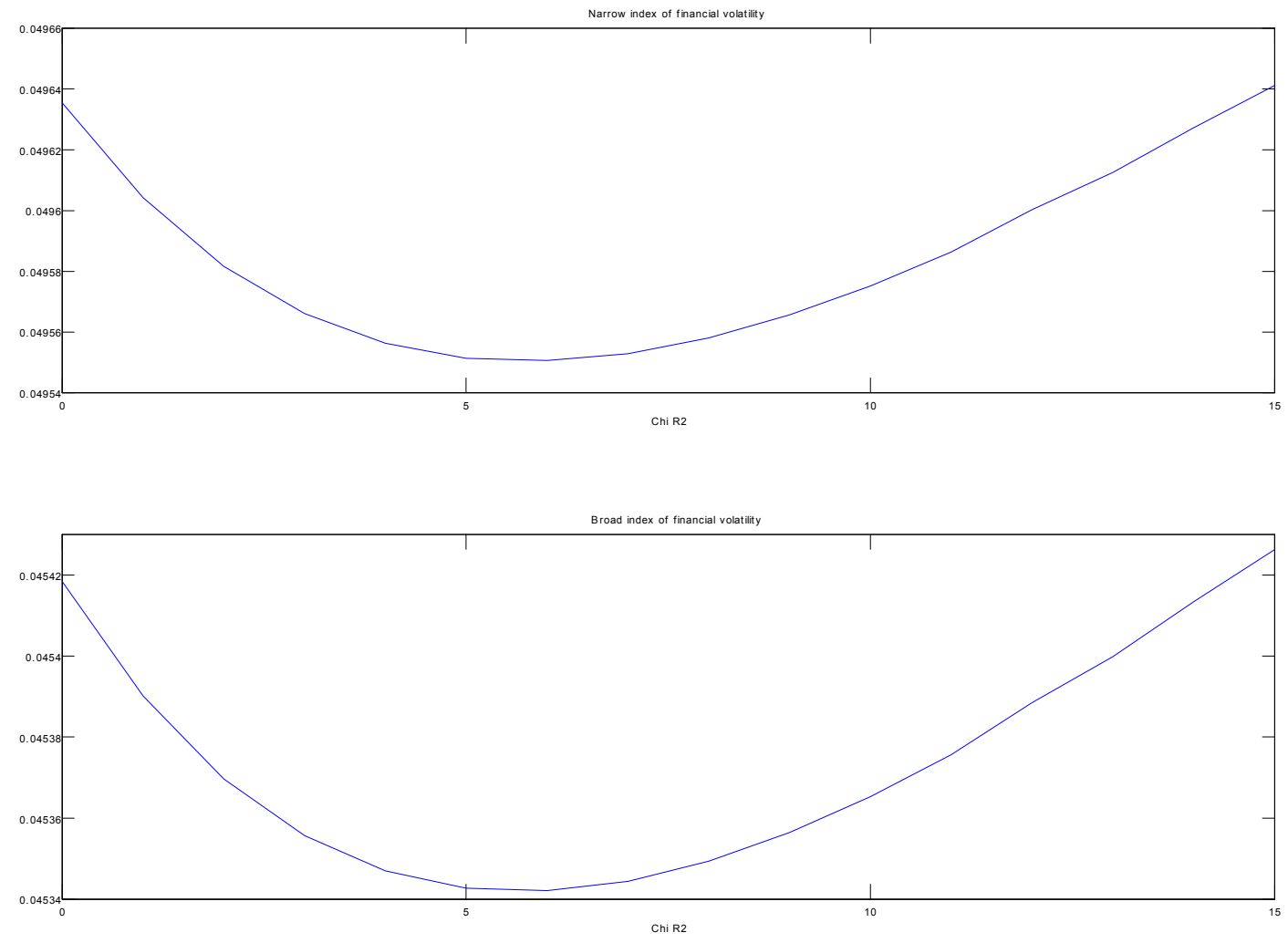

Note: $\chi_{2}^{R}$ is a positive parameter that measures the response to credit growth in the countercyclical reserve requirement rule. The vertical axis measures economic volatility, in terms of a composite index of macroeconomic volatility and a composite index of financial volatility, both narrow and broad, as defined in the text. 
Figure 5

Index of Economic Volatility and Aggressiveness of the Countercyclical of the Reserve Requirement Rule Weight of 0.8 to Macro, 0.2 to Financial Volatility
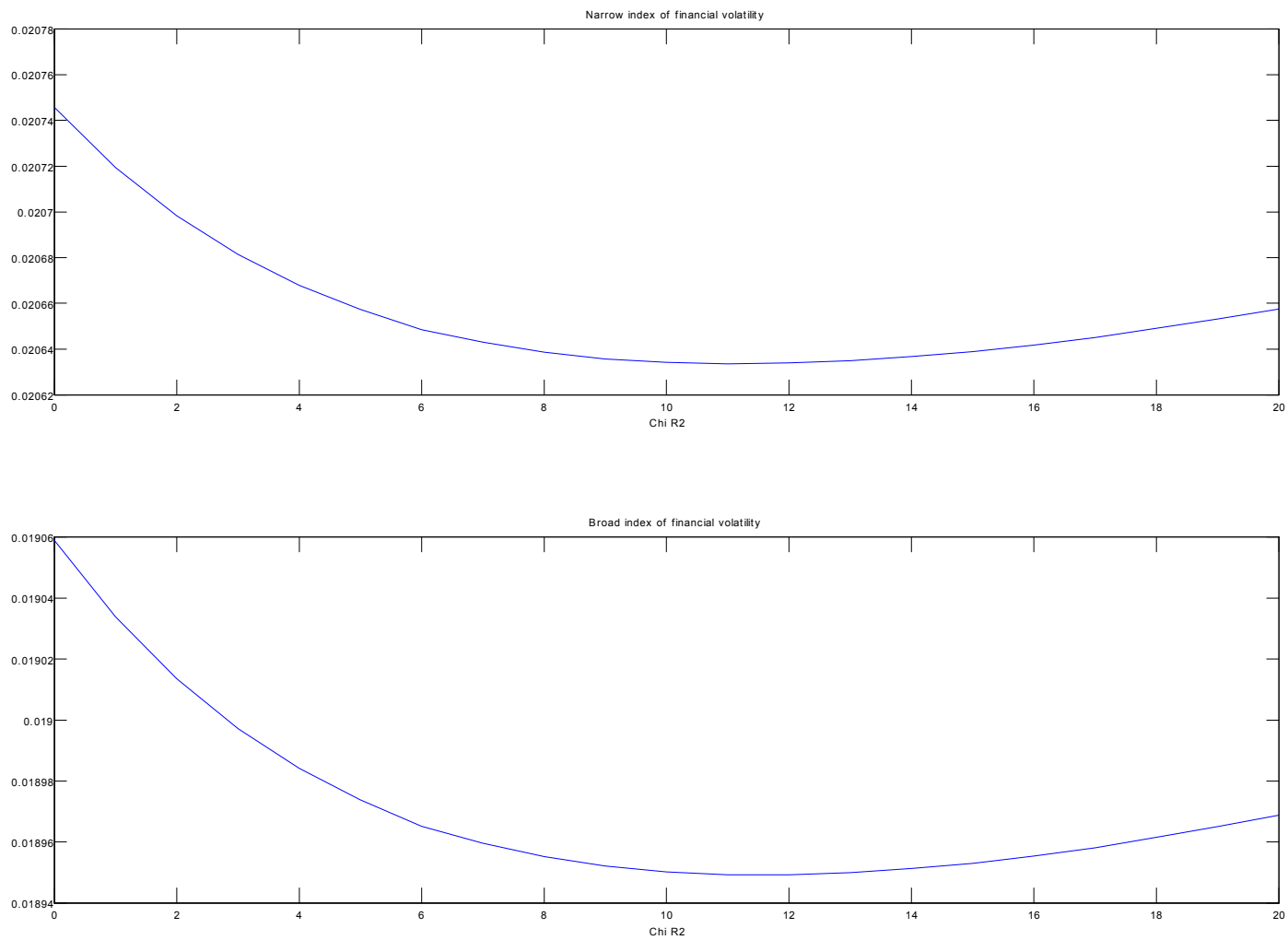

Note: $\chi_{2}^{R}$ is a positive parameter that measures the response to credit growth in the countercyclical reserve requirement rule. The vertical axis measures economic volatility, in terms of a composite index of macroeconomic volatility and a composite index of financial volatility, both narrow and broad, as defined in the text. 